\title{
Toward a Microeconomics of Growth ${ }^{1}$
}

\author{
Robin Burgess \\ LSE and CEPR
}

Anthony J. Venables

LSE and CEPR

JEL classification nos: O10, O12, O14.

Keywords: Growth, development, structural change, clustering.

\section{Addresses}

R. Burgess

Dept of Economics

London School of Economics

Houghton Street

London WC2A 2AE, UK

r.burgess@1se.ac.uk

http://econ.lse.ac.uk/staff/rburgess/

\author{
A.J. Venables \\ Dept of Economics \\ London School of Economics \\ Houghton Street \\ London WC2A 2AE, UK \\ a.j.venables@1se.ac.uk \\ http://econ.lse.ac.uk/staff/ajv/
}

World Bank Policy Research Working Paper 3257, April 2004

The Policy Research Working Paper Series disseminates the findings of work in progress to encourage the exchange of ideas about development issues. An objective of the series is to get the findings out quickly, even if the presentations are less than fully polished. The papers carry the names of the authors and should be cited accordingly. The findings, interpretations, and conclusions expressed in this paper are entirely those of the authors. They do not necessarily represent the view of the World Bank, its Executive Directors, or the countries they represent. Policy Research Working Papers are available online at http://econ.worldbank.org.

\footnotetext{
${ }^{1}$ Paper written for the Annual Bank Conference on Development Economics, Bangalore, India, 2003. We are grateful to Bronwen Burgess, Gur Offer, Diego Puga, Steve Redding, Marit Rehavi and Sidney Winter for comments on an earlier draft.
} 


\section{Introduction}

Growth and development typically involve the creation of new economic activities. New productive sectors develop, and old activities come to be performed in radically different ways. Evidence from both economic history and economic development suggest that this process of structural change is central to increasing growth and raising standards of living (Rostow 1960; Hirshman 1958; Sokoloff 1986). Indeed, many early development theories viewed development as a process of transformation from agriculture to manufacturing (Lewis 1954). Labor productivity is higher in the newly developing sectors, and the reallocation of labor also pulls up productivity in traditional sectors.

Not much is known, however, about the likely pattern of structural change in future development. What sorts of new activities will take place in the fast-growing countries of the $21^{\text {st }}$ century? Are there new "patterns of development", analogous to those Chenery and others identified in the 1960s? And most importantly, what factors are conducive to fostering these new activities at the microeconomic level?

In this paper we explore some of the issues surrounding the development of new activities in low-income countries. Our central thesis is that this process is frequently "lumpy", manifesting itself in rapid growth of particular regions or sectors. Spatial inequalities tend to increase during periods of rapid economic development. At the sector level, many fast-growing cities, regions and countries have export specializations in a very narrow range of activities. Recognition of these facts requires a reorientation of the analytical frameworks and empirical approaches that are used to investigate growth.

We find it useful to divide the determinants of a location's growth performance into two groups that we term " 1 st advantage" and " $2^{\text {nd }}$ advantage" (terminology adapted from economic geographers' notions of first-nature and second-nature geographies). The term " 1 st advantage" refers to the conditions that need to be met to provide the environment in which 
new activities can most profitably be developed. The term " 2 nd advantage" refers to the fact that many aspects of growth are self-reinforcing. The lumpiness of the growth process suggests the presence of increasing returns so that a location's advantage in an activity derives, in part, from the very fact that it has a presence in the activity. It is the interaction of $1^{\text {st }}$ and $2^{\text {nd }}$ advantages that yields the growth patterns we observe, and that makes it so difficult to pin down the causes of rapid economic growth. Increasing returns and cumulative causation have featured in many analyses of economic development, from the development economists of the 1950s through to Murphy, Shleifer and Vishny (1989). We think it important, however, to recognize that key aspects of returns to scale are often found at the micro level - within very narrow sectors of production or small districts of a city. A microeconomics of growth is needed to capture these sectorally and spatially concentrated processes

Cross-country comparisons, though useful in identifying some of the important $1^{\text {st }}$ advantages, cannot provide policy insights into what will drive growth in a particular location. Instead a bottom-up approach is required, where microeconomic studies are used to build up evidence base on what works in different countries, regions and sectors. This empirical work is facilitated by increased availability of micro data. Regional, city, firm and household data are now available for a wide range of countries. The institutional context in which policies are implemented and accumulation decisions are made affects economic performance (see Djankov and others 2003; Rodrik 2003). This makes it natural to study single countries and makes it less clear what one learns from cross-country regressions where these factors cannot typically be controlled for. Furthermore it is clear that the actors in development work are highly diverse. Policy and institutional innovations are happening all the time and are being implemented by central government, local government, nongovernment organizations and local communities. Evaluating these innovations requires careful microeconomic work at the 
subnational level.

Our route for investigating these issues is to begin in section 2 with a selective overview of the facts concerning the growth of new productive activities in developing countries. We then outline a framework of analysis that can be used to think about the determinants of structural change and growth, developing our $1^{\text {st }}$ and $2^{\text {nd }}$ advantage distinction (section 3). Section 4 goes into more detail, outlining what we know about some of the key elements of $1^{\text {st }}$ and $2^{\text {nd }}$ advantage based on the available evidence. Section 5 turns to work on India, as an illustration of how our approach can be used to generate insights into the microeconomic determinants of structural change. Section 6 concludes.

\section{Aspects of Modern Economic Growth}

Much of the recent work on the determinants of growth has focussed on country aggregate growth performance. The most popular examples of this are cross-country growth regressions, typically regressing growth performance on a number of explanatory variables. While these regressions reveal something of the importance of $1^{\text {st }}$ advantages, such as human capital, good policy and institutions, and open trade regimes, many of the results are not particularly robust (see Djankov and others 2003; Rodrik 2003). Furthermore, they fail to capture some key aspects of modern economic growth. An aggregate approach overlooks two of the most important aspects of the performance of many developing countries: the uneven performance of different regions within each country, and the different performance across sectors.

\section{Spatial Concentration}

For many countries development is associated with increasing spatial inequality. The finding of rising spatial inequality during development dates back at least to Williamson (1965) and has been confirmed in many studies since (e.g. the studies of urban concentration by Shishido 
and Wheaton 1982 and Henderson 1999). This increase in spatial inequality often arises from spatial concentration in the development of manufacturing. We see this most clearly in data for large countries. In section 5, for example, we show that states in southern India have come to prominence in manufacturing. In Mexico manufacturing has become highly concentrated in regions that border the US, and spatial variation in per capita incomes has increased dramatically since the mid 1980s (Cikurel 2002). In China, Demurger and others (2002) chart increasing spatial inequalities in per capita GDP from the mid 1980s. Coastal provinces experienced the greatest decline in the share of agriculture in employment and output, and the fastest growth of per capita income.

The spatial concentration of new activities also occurs at a much finer level of disaggregation than suggested by the state or province level data above. The polarization of activity in a number of "city regions" in Asia is documented by Aranya (2002). Bangalore is a good example; the city is estimated to account for $25 \%$ of India's software exports, with some 100,000 workers in the city producing $3 \%$ of India's total exports. Within cities, we know that particular sectors frequently cluster in particular districts (see, for example, the study of India by Chakravorty and Lall 2003).

Spatial concentration is most dramatically demonstrated by the role of urbanization, and of mega-cities, in development. The number of cities in the world with a population of more than 1 million went from 115 in 1960 to 416 in 2000; for cities of more than 4 million, the increase was from 18 to 53; and for more than 12 million, from 1 to 11 (Henderson and Wang 2003). Henderson (1999) finds that national urban concentration (the dominance of the largest city) rises with growth from low-income levels, peaks at low-middle levels (per capita 1987 PPP income of around \$2,500) and then declines. This tells us that, despite the massive diseconomies associated with developing country mega-cities, there are even more powerful economies of scale making it worthwhile for firms to locate in these cities. Urbanisation is 
one of the clearest features of the development of manufacturing and service activity in developing countries, yet discussion of urbanisation is strangely absent from the economic analyses of growth and development.

\section{Sectoral concentration}

There is a substantial but rather old development economics literature on the changes in countries' production structures typically associated with development, deriving from Chenery's "normal" pattern of sectoral change (Chenery 1960; Chenery and Taylor 1968). Using a trade framework, the specialization of countries has been researched by a number of authors, for example Leamer $(1984,1987)$ and Schott $(2003)$, who find "development paths" linking the structure of countries' production to their factor endowments.

These studies are, however, based on sector aggregate data, and seem to miss key aspects of modern specialisation. What do we know about specialisation during development in the $21^{\text {st }}$ century? Globalization has created the possibility of trade in new products and services, and of a much finer pattern of specialisation. The impact of new technologies is perhaps best illustrated by the experience, already referred to, of India (and Bangalore in particular), which is able to export labor services embodied in information technology and services. The finer pattern of specialisation arises with the growth of production networks. Component parts and semi-finished goods can cross borders multiple times, and countries are able to engage in "vertical specialisation", just producing one very narrowly defined part of the product. Data on these activities can be hard to obtain, as they do not correspond to the standard commodity classifications of trade. However, one of the fastest growing elements of world trade has been trade in parts and components, now accounting for around $30 \%$ of world trade in manufactures (Yeats 1998).

A striking feature of growth has been the fact that many countries have done well in a 
few extremely narrow product segments. Once again, India's success in software products is an example. Hausmann and Rodrik (2002) look in detail at the exports to the US of Bangladesh, Pakistan, Honduras, Dominican Republic, Korea, and Taiwan, using data at the 6-digit level (eg 'hats and other headgear knitted or from textile material not in strips'). Even at this very fine level of disaggregation, for each of these countries, their top four product lines account for more than $30 \%$ of exports to the US. Furthermore, there is surprisingly little overlap in the top product lines of quite similar countries. For example, Bangladesh is successful in exporting shirts, trousers and hats (but not bed linen or footballs), while Pakistan does well in bed linen and footballs. Only six product lines are in the top 25 for both these countries. Hausmann and Rodrik conclude that 'for all economies except possibly the most sophisticated, industrial success entails concentration in a relatively narrow range of high productivity activities' (p26).

These findings are not inconsistent with the broad pattern of 'development paths' identified by earlier researchers. However, they indicate that these paths are only part of the story. Aggregate studies can conclude that a country has a comparative advantage in a laborintensive activity such as textiles, but provide no basis for predicting what particular product line will be produced. To understand the economic success stories we must also know why it is that this spatial and sectoral concentration occurs.

A corollary of spatial and sectoral concentration is that exports are essential; narrow sectoral specialisation can develop only if output is exported from the city, region or country. Increasing shares of exports in income are observed for many countries. Between 1980-82 and 1998-2000 the export to GDP ratio for the East Asia and Pacific region rose from $22 \%$ to $41 \%$, and for South Asia from $8 \%$ to $14 \%$, (compared to, from $20 \%$ to $23 \%$ for the world as a whole, and $28 \%$ to $29 \%$ for Sub-Saharan Africa). ${ }^{2}$

\footnotetext{
2 Averages for periods 1980-82 and 1998-2000, source World Development Indicators.
} 


\section{Analytical Framework: $1^{\text {st }}$ and $2^{\text {nd }}$ Advantages}

To understand the microeconomic determinants of growth we divide the driving factors into two sets, operating in distinct ways. One set we label first advantage. These are the factors that can be viewed as pre-conditions for the development of new activities; they are - loosely - necessary but not sufficient conditions for growth. They include most of the factors that traditional theory has focussed on, such as access to inputs (labor skills and capital), access to markets, provision of basic infrastructure and institutional environment. These factors shape the business environment in which firms make investment and location decisions. The other group of factors we call second advantage. Second advantage factors inherently have some element of increasing returns to scale, so may give rise to processes of cumulative causation. They are a function of the past and present level of activity in a location or sector and include factors such as technological capability, knowledge spillovers, thick market effects and networks. For example, a particular city may be a good place to set up a business, precisely because of spillovers from existing similar businesses. The increasing returns are typically sector and/or location specific, and are often external to the firm. It is this combination of sector and location specific increasing returns to scale and external effects that gives rise to the lumpy performance described in the previous section.

Before looking at the elements of $1^{\text {st }}$ and $2^{\text {nd }}$ advantage in detail, we spend the rest of this section outlining some theory on how they interact to shape the growth process. To this end, we draw on work on sub-national inequalities (Venables 2003). However, the rather broad lessons we draw have wider applicability, to international and intersectoral developments, as well as to sub-national ones (see for example Puga and Venables 1999 and Fujita, Krugman and Venables 1999 for more fully developed models).

Differing levels across regions mainly reflect country size; it is the change through time that 
Suppose that there are many potential locations in which a particular activity or set of activities could take place. For our purposes a location can be thought of as a town or city, and the activity as a particular industrial sector, although alternative broader interpretations are also possible. The private return to creating a job in this activity in location $i$ is $\pi_{i}$,

$$
\pi_{i}=q_{i} a\left(n_{i}\right)-\left(w(N)+t_{i}\right)
$$

The first term on the right hand side of this expression is the value of output from the job. The first part, $q_{i}$, measures the $1^{\text {st }}$ advantage of location $i$, capturing all aspects of the environment that, while specific to the location, are exogenous for the firms and sector under study. We rank locations such that location 1 has the highest value of this term, location 2 the next highest, and so on. An example of this might be, for an export activity, the distance of the location from the port, with more remote locations having worse $1^{\text {st }}$ advantage (a lower value of $q_{i}$ ). In the next section we offer a more complete view of the determinants of $1^{\text {st }}$ advantage.

The second part is a function $a($.$) of the level of activity in location i$, as measured by employment, $n_{i}$. This function measures $2^{\text {nd }}$ advantage, and we assume that it is increasing and concave, capturing increasing returns to scale that become progressively exhausted. In contrast to $1^{\text {st }}$ advantage which is location specific, $2^{\text {nd }}$ advantage is represented by the same function at all locations, although the function is evaluated at location specific values of the endogenous variable, $n_{i}$. Thus, if one location has a higher employment level in the activity than another, then, because of increasing returns, it will also have a high value of $a\left(n_{i}\right)$ and higher output per worker. $2^{\text {nd }}$ advantage can originate from different mechanisms, including knowledge spillovers and the acquisition of technical know-how; the development of a dense network of local suppliers of specialist inputs to production; and the presence of thick local labor markets in particular sector specific skills. We discuss these elements of $2^{\text {nd }}$ advantage in more detail in section 4 .

we draw attention to. 
The remaining term, $w(N)+t n_{i}$, is the cost of employing labor. $w(N)$ is the opportunity cost of labor, i.e. its marginal product (and wage) in some alternative use. This wage is a function of total industrial employment, $N \equiv \Sigma_{i} n_{i}$, rising as workers are drawn out of agriculture into the new activities, $w^{\prime}(N)>0 . t n_{i}$ is the cost-of-living in a city of size $n_{i}$; this could be a congestion cost or, in the tradition of the urban economics literature, the rent plus commuting cost that urban workers to have to pay. It is a source of diminishing returns, preventing all activity from concentrating in a single location.

We are now in a position to address the following question. Suppose that total modern sector employment, $N=\Sigma_{i} n_{i}$, is exogenous and increasing through time. As jobs are created they go to locations that offer the highest return (highest value of $\pi_{i}$ ). What form does growth take in this economy? Equilibrium patterns of development are illustrated in Figures 1 and 2. The horizontal axis is total employment, $N$, so the economy moves to the right along this axis through time. The vertical axis is employment in each location and the curves on the figure illustrate equilibrium employment in each location, $n_{i}{ }^{3}$

Figure 1 illustrates the case where there is no $2^{\text {nd }}$ advantage, so $a\left(n_{i}\right)$ is a constant, the same for all locations. There is however $1^{\text {st }}$ advantage heterogeneity, and this maps in a continuous way into outcomes. Better locations (those with low $i$, and hence high $q_{i}$ ) get activity sooner and are larger than worse ones. Thus, the curve $n_{1}$ gives employment in the location with the best $1^{\text {st }}$ advantage, $n_{2}$ in the second best, and so on. Increasing $N$ causes both intensive and extensive growth, enlarging existing locations and making it profitable for new locations to gain activity. Figure 2 gives the equilibrium when $2^{\text {nd }}$ advantage returns to scale are present. Development is much less continuous; once a particular location starts to attract activity, increasing returns cut in and lead to rapid growth. Outcomes are determined by a combination of the $1^{\text {st }}$ advantage of each location, determining the sequencing, and the 
$2^{\text {nd }}$ advantage of increasing returns, determining the growth path of each location. ${ }^{4}$

We learn several things from comparison of Figures 1 and 2. The first is that development, in the presence of $2^{\text {nd }}$ advantage, is uneven; locations do not develop in parallel but in sequence. Second, development is more spatially concentrated. For any value of total employment, $N$, activity is concentrated in fewer and (on average) larger locations. Third, $1^{\text {st }}$ advantage determines the order of development and, at any point in time, predicts which locations are successful and which are not. However, the dependence of performance on $1^{\text {st }}$ advantage is not continuous. For locations just at the threshold of development small differences in $1^{\text {st }}$ advantage can translate into large differences in outcomes; if two locations have very similar $1^{\text {st }}$ advantage, then a small improvement could cause one to overtake the other, and gain industry sooner. Conversely, for locations well below the current threshold an improvement in $1^{\text {st }}$ advantage does not confer any immediate payoff in terms of attracting the activity. And amongst the set of active locations, differences in $1^{\text {st }}$ advantage have little effect on employment, as they are dominated by acquired $2^{\text {nd }}$ advantages.

What about the efficiency of the equilibrium development pattern? In the absence of $2^{\text {nd }}$ advantage, the development path is efficient - there are no market failures in the simple structure we have outlined. However, the presence of $2^{\text {nd }}$ advantage adds two distinct types of market failure. Within existing locations, private agents do not take into account the fact that an expansion of employment raises the productivity of workers already in the city, meaning that private incentives to expand employment in the location are too small. Additionally, there is a coordination failure involved in the development of new locations and activities. In Figure 2 these are initiated when they become privately profitable for an individual small firm. However, the profits from development of a new location or activity would be higher if

3 The figures are generated from a simple numerical example, available on request.

4 The main point is the rapid growth of new locations; the jagged saw-tooth effect occurs as some workers are drawn from existing locations, and is not central to the argument. 
firms could coordinate their decisions and act collectively. These two market failures combine to have two effects. One is that there is a tendency for cities to be too large, because of the difficulty of initiating activities in new locations. The other is that the overall return to job creation, $\pi_{i}$, is too small. If the rate of growth of jobs depends on $\pi_{i}$, then employment growth is less than optimal. In an extension of the present model it is possible that there are multiple equilibria, and countries can become stuck in a low-level equilibrium. Essentially, the slower is employment growth the worse is the coordination failure (as a new city only achieves increasing returns relatively slowly); but a worse coordination failure means lower

return to job creation and hence slower employment growth. Thus $2^{\text {nd }}$ advantage at the local level causes cumulative causation at the aggregate national level.

Summing up, the theory tells us that the combination of $1^{\text {st }}$ and $2^{\text {nd }}$ advantage offers an explanation of the lumpiness of development. It says that both advantages need to be considered together - changes in $1^{\text {st }}$ advantage alone do not necessarily translate into changes in outcomes. And it says that there is market failure, and hence potential scope for policy. Of course, the form any such policy should take depends on the detailed ingredients of $1^{\text {st }}$ and $2^{\text {nd }}$ advantage, and it is to enumerating these that we now turn.

\section{A Microeconomic Agenda for Growth}

In this section we confront our analytical framework with some evidence on the drivers of growth. This allows us to begin to sketch out a microeconomic agenda for growth. We do not intend to be comprehensive, instead we focus on several areas including institutions, skills, technology, and trade. We have several objectives. One is to illustrate in each of these contexts the distinction between $1^{\text {st }}$ and $2^{\text {nd }}$ advantages, and thereby make concrete the somewhat abstract discussion of the previous section. Another is to provide evidence for some of the increasing returns mechanisms, and give a sense of their importance. This 
section also points to the sort of detailed microeconomic information that is needed by policy makers in order to encourage growth within a narrow geographical jurisdiction. We develop this theme further in section 5, with examples of policies that have affected the pattern of manufacturing growth across Indian states and industries.

\section{Property Rights and Contracts}

Strengthening of economic institutions is often seen as critical to promoting innovation, investment and growth (North 1990; Aghion and Howitt 2003). Recent cross-country papers provide evidence in this direction. Acemoglu, Johnson and Robinson (2001) find that insecure property rights are associated with lower income per capita. Hall and Jones (1999) show that a social infrastructure variable (which captures both the quality of government institutions and openness to trade) is positively associated with income per capita. How to map from these findings into concrete policy suggestions, however, is not clear.

Here microeconomic evaluation is pointing the way. For a given location we want to understand which elements of the property rights regime are central to engendering innovation and growth. Strengthening property rights over land appears to be an important element of $1^{\text {st }}$ advantage. For example, the 1978 rural reforms in China, which entailed a shift from collective to household farming, are credited with engendering increases in agricultural productivity (Lin 1992) and an explosion in town and village enterprises which have been the engine of growth in China up to the mid-1990s (Qian 2003). In a similar vein, Banerjee, Gertler and Ghatak (2002) show that a government program which increased tenurial security in West Bengal had a large positive effect on agricultural productivity. Field (2002) finds that issuance of property titles to urban households in Peru led to an increase in labor hours and a shift in labor supply from work at home to work in the outside market. Besley and Burgess (2000) find that land reform acts passed in Indian states account for about ten percent of the 
overall fall in poverty across the 1958-1992 period.

Effective institutions for enforcement of contracts are another source of $1^{\text {st }}$ advantage. Djankov and others (2002) examine court procedures to evict a tenant or to collect a bounced check in 109 countries. They find that common law countries exhibit greater procedural formalism which is associated with slower judicial proceedings, more corruption, less consistency, less honesty, less fairness in judicial decisions, and inferior access to justice. Johnson, McMillan and Woodruff (2002a) surveyed small manufacturing firms in Russia, Ukraine, Poland and Romania, and found that perceived effectiveness of courts in resolving commercial disputes affected the propensity of entrepreneurs to reinvest profits. Well functioning courts also encouraged entrepreneurs to form new trading relationships with customers and suppliers (Johnson, McMillan and Woodruff 2002b). Besley and Burgess (2003a) find that long backlogs in state high courts in India are associated with lower output in informal sectors where contract enforcement problems may be acute.

Where laws of contract are inadequate informal relationships such as business networks may substitute for courts in allowing deals to be made. Development of these networks is typically fostered by proximity and by frequency of interaction. This is a $2^{\text {nd }}$ advantage. A locality with a tightly knit business sector develops this advantage, helping to explain why new economic activities tend to be clustered. For example, McMillan and Woodruff (1999) use the amount of trade credit extended by small manufacturing firms to suppliers and customers in Vietnam as a measure of business trust. They find that relationships of longer duration, visits to premises and being part of the same business network all enhanced the propensity to extend trade credit. They argue that relational contracting within business networks has enabled manufacturing to flourish in Vietnam even in the absence of formal institutions. Formal institutions to support finance and contracting, however, will be required as firms grow (McMillan and Woodruff 2002). 


\section{Regulation}

A second major element of $1^{\text {st }}$ advantage concerns the degree to which government regulation impedes entrepreneurship and the emergence of new activities. Economic theories which saw the state as playing a central role in directing and coordinating economic development led to a huge variety of regulations being put in place. However, there is increasing empirical evidence that (well-intentioned as the architects of regulation may have been), regulation has been neither an engine of economic development nor a boon for the poor.

One problem is that government regulations can be exploited to expropriate entrepreneurs. Surveys of start-up firms, for example, reveal that more than $90 \%$ of Russian managers had to make "extralegal" payments to secure government services or a business license (Johnson, McMillan and Woodruff, 2002a, 2002b). Those firms who were most concerned about corruption invested $40 \%$ less than those who were least concerned. Government regulation of entry can also impede entrepreneurship and innovation. Djankov and others (2002) collect data on the time and number of procedures an entrepreneur must complete to officially open a business in 85 countries. They find pronounced variation across countries with the number of regulations to set up a business being larger in poorer countries. Heavy regulation of entry is associated with less democratic governments, greater corruption and larger unofficial economies. They argue that this is in line with a public choice view of regulation as being put in place by officials or insiders intent on extracting rents.

Findings for labor regulation point in a similar direction. Botero and others (2003) study labor regulations in 85 countries and find that heavier regulation of labor is associated with a larger unofficial economy, lower labor force participation and higher unemployment. Besley and Burgess (2002) find that pro-worker labor regulations in Indian states are associated with lower output, employment, investment and productivity in registered or 
formal manufacturing but higher output in informal manufacturing (see section 5). A survey of 1000 manufacturing establishments drawn from 10 Indian states revealed that managers would be willing to reduce their work force by $16-17$ percent if there was greater labor market flexibility, this indicating the negative impact of labor regulation on firm productivity (Dollar, Iarossi and Mengistae 2001).

Of course, there are a number of areas where government regulation is called for. For example, in the area of finance, legal and regulatory institutions that protect investors and creditors from expropriation, are critical to engendering financial development. Glaeser, Johnson and Shleifer (2001) argue that in Poland, strict enforcement of the securities law by a highly motivated regulator was associated with a rapidly developing stock market. In contrast, in the Czech Republic, hands-off regulation was associated with a moribund stock market. La Porta and others (1998) find that common law countries provide investors and creditors with greater protection than do civil law countries, and this results in larger debt and equity markets (La Porta and others 1997) and faster economic growth (Levine 1998). Given that external finance becomes increasingly important as firms grow, identifying the set of institutions which support financial development in a given location is critical.

Nevertheless, it is frequently the case that removal of the impediments to entrepreneurship via regulatory change can be a powerful mechanism for attracting new firms to a location. As employment in a location increases various types of $2^{\text {nd }}$ advantage kick in as a result. Thicker markets imply better access to inputs and customers, skilled workers and external finance become more available, and firms benefit from technological upgrading. The emergence of entrepreneurs as a powerful political class can also lead to demand for institutions which protect property and support contracting and finance. Stern (2003) argues that improvements in the investment climate can be a powerful means of engendering increasing returns to scale along these different dimensions. 


\section{Education and Skills}

Both theory and empirical evidence suggest that investment in human capital is central to promoting innovation and growth (Aghion and Howitt 1998). The best estimates of the rate of return to education in developing countries (from micro-econometric studies that take endogeneity and measurement errors issues seriously) line up with those for developed countries -- each additional year of schooling is associated with a 6-10\% increase in earnings. Duflo (2001), for example, uses a large primary school building project in Indonesia to establish that the economic returns to extra schooling provided via this program lie in this range. This evidence appears robust across both methods and locations (Card 1999). After accounting for measurement error, the effects of changes in educational attainment on income growth in cross-country data are at least as great as microeconometric estimates (Krueger and Lindhal 2001). These results suggest that access to education is an important source of source of $1^{\text {st }}$ advantage in a location.

This still leaves open the central question of how such an expansion in education is best achieved. New work in the area is addressing this, looking at the market conditions under which it is provided and the incentives faced by education providers. One strand of research focuses on policy design. Banerjee and others (2003) have used randomized experiments to look at whether NGO implemented remedial education and computer assisted learning programs in India affected learning. Randomized intervention has also been used in western Kenya to evaluate whether improving the quality of education by increasing the supply of textbooks and improving child health affect attendance and attainment (Glewwe, Kremer and Moulin 2000; Kremer and Miguel 2001). Another strand focuses on whether there needs to be changes in the organization of policy delivery. Political representation, decentralization and involvement of non-government organizations and the private sector are 
major issues here (Chattopadhyay and Duflo 2001; Hsieh and Urquiola 2002).

Educational levels raise the return to creating a job in a particular location, and are thus an element of $1^{\text {st }}$ advantage. The human capital embodied in skills that workers acquire while doing a job can also spillover to other firms, for example via job turnover. A worker may become familiar with a particular technology and can use this knowledge in other firms. The magnitude of these spillovers will increase as the level of economic activity in a given location increases, and constitute a source of $2^{\text {nd }}$ advantage. There are both micro-level and more aggregate studies of the importance of these effects. Firm level studies are reviewed in Evenson and Westphal (1995) who find extensive evidence of learning by doing within firms and of spillovers between firms. They also report that diffusion of technology between firms comes largely from the turnover of skilled workers and managers. There is also evidence of human capital externalities whereby increasing the number of skilled workers in a location brings external benefits for other workers (Moretti 2003; Klien 2003).

\section{Trade and Market Access}

We have already argued (section 2) that exporting is an important aspect of modern economic growth. Barriers to exports are, in our terminology, a source of $1^{\text {st }}$ disadvantage, reducing the return to job creation. While this suggests the case for liberal trade policy, several caveats need to be made. Indeed, the role of trade policy in economic development has been the subject of an intense and passionate debate over the last decade.

Our central thesis is that the mapping from $1^{\text {st }}$ advantages to outcomes is not straightforward. The removal of trade barriers is not a sufficient condition for growth, as has been confirmed by the empirical literature. While samples of successful countries indicate strong export performance (Dollar and Kray 2000, Bhagwati and Srinivasan 1999), crosscountry regressions attempting to establish a causal link between open trade policy and 
growth have failed to come up with robust findings (Rodrik and Rodriguez 2000). This is partly because of the complex interaction between $1^{\text {st }}$ and $2^{\text {nd }}$ advantages. Thus, some authors have argued that there are instances, especially in very poor economies, where liberalization is in fact detrimental to growth, by inhibiting infant industries and the local accumulation of knowledge (Krugman 1981, Hausmann and Rodrik 2002, Young 1991). Others emphasize that, in the presence of capital market imperfections, liberalization exacerbates income inequality within countries, imposing high costs on less favored regions, social groups or sectors of activity, and with ambiguous effects on average performance (see Banerjee and Newman 2003, Trefler and Zhu 2001).

Once again, micro-based research is going to be more useful than broad-brush crosscountry work in informing the design of policy in particular countries. For example, Aghion and others show that technological capability and institutional conditions determine whether industries in India benefited from or were harmed by liberalization in 1991 (see section 5). Using Chilean plant level data Pavcnik (2002) find that import liberalization led to within plant productivity improvements. Other recent work on firm level data from a number of countries has also drawn attention to the productivity gains from exporting (HallwardDriemeier and others 2002). Detailed studies of the impact of trade reform on poverty have been undertaken by McCulloch, Winters and Cirera (2002).

Geography, as well as trade policy, is an important determinant of access to markets in which to sell output and from which to source intermediate and capital goods. Evidently, much of the success of the northern border region of Mexico is a direct consequence of its proximity to the US, and coastal regions of China do well because they are on the coast. A number of studies have tried to quantify the importance of these geographical $1^{\text {st }}$ advantages. Gallup and Sachs (1999) regress national per capita income on four variables; a measure of the endowment of hydro-carbons, a dummy variable for the incidence of malaria, and two 
measures of geography; internal geography, captured by the proportion of population within $100 \mathrm{~km}$ of the coast, and external geography, as measured by shipping costs (the cif/fob ratio). They find that these four variables account for $69 \%$ of the per capita variation in incomes across countries. Frankel and Romer (1999) and Redding and Venables (2004) also show how geography based measures are important determinants of levels of per capita income.

In this area, as with others, micro-economic detail is important. The market access of a location depends on its infrastructure and the quality of internal and external transport links with which it is served. Limao and Venables (2001) construct an index of infrastructure quality, and show how a deterioration of infrastructure from the median to the $75^{\text {th }}$ percentile raises transport costs by $12 \%$ and reduces trade volumes by $28 \%$. Effects are even greater for landlocked countries. Numerous studies of port quality point to the damaging effects of delay, be it due to capacity constraints or poor administration. And in this area too, there are $2^{\text {nd }}$ advantage effects. Both the cost of shipping and the frequency of service are subject to increasing returns to scale, reducing costs for ports with a high turnover.

\section{Thick Market Effects}

Thick market effects arise when increased volumes of trade in a particular market increase the efficiency with which the market operates. A number of mechanisms give rise to such effects, including improved matching of buyers and sellers, reduced monopoly or monopsony power, and the development of specialist suppliers - a finer division of labor. These effects are all fundamentally $2^{\text {nd }}$ advantages; increasing the scale of activity in a market creates benefits for other consumers, workers, or firms.

These thick market effects are important in many markets. In the supply of finance, we have already seen how trade credit can be extended more readily in tightly knit business 
networks. Thickening financial markets in a particular location enables external finance to become more available and less costly, allowing firms to expand in size and to upgrade the technologies they employ (Rajan and Zingales 1998). This in turn leads to greater demand for financial services. Complementary institutions like credit rating agencies and more specialized finance providers like venture capital firms often develop as economic activity in a location increases.

In the labor market, the thick market effect is usually known as labor market pooling, operating in two ways. One is that workers and firms are better able to match their specific skills and needs the thicker the market. The other is that scale reduces the risk of there being excess supply or demand of specific skills (if, for example, there are firm specific shocks). This in turn makes it more worthwhile for workers to invest in skill. Some evidence in support of these hypotheses is presented in Rosenthal and Strange (2003).

Turning to the product market, firms generally derive benefit from being located close to markets for their output and to suppliers of intermediate inputs. Such input-output linkages are a source of $2^{\text {nd }}$ advantage, as firms seek to locate close to other firms with which they are transacting. Forward and backward linkages between these firms constitute a pecuniary externality which raises productivity in the sector/location concerned, and gives rise to clustering of activity. Fujita, Krugman and Venables (1999) model this theoretically, and on the empirical side Holmes (1999) presents evidence of US firms locating to gain the benefits of proximity to input suppliers. A good deal of case-study evidence points to the importance of dense networks of specialist suppliers. For example, Hobday (1995) studies a number of situations in which initial multinational investments in developing East Asia created backward linkage effects to local suppliers. Examples include computer keyboards, personal computers, sewing machines, athletic shoes, and bicycles in Taiwan. The initial foreign investments created demand for local suppliers and improved their quality, productivity, and 
product diversity. Large numbers of local firms entered to supply components or assembly services to multinational firms. This growth of component and other intermediate-goods supply and productivity in turn created a forward-linkage effect to the final-goods producers, drawing in more multinationals and domestically-owned firms. There then followed a second-round backward-linkage effect and so forth. In some cases (e.g, bicycles, computers) local firms eventually displaced the original multinational entrants.

\section{Technology and Productivity}

Success in a particular product line requires mastery of the technology. This point is particularly emphasised in the work of Sutton (2002) who argues that to compete successfully, a firm must be within a relatively small window, defined by production costs and product quality. Acquiring capability requires fixed outlays on $R \& D$ and related activities, so is associated with increasing returns to scale. There may also be learning-bydoing, amplifying such effects. For Hausmann and Rodrik (2002) development of successful activities requires experimentation, with firms having to incur upfront expenditures to learn about the comparative costs of their location.

Knowledge spillovers mean that productivity depends on the activities of others, and are a source of $2^{\text {nd }}$ advantage. These spillovers are often sector and location specific. Hausmann and Rodrik (2002) argue that the results of experiments become public knowledge, but the knowledge revealed is specific to the activity/ location combination. If knowledge spillovers occur through job turnover they are also likely to be spatially concentrated. Sutton (2002) argues that knowledge is embodied in teams of workers, and that it is difficult to move an entire team between locations.

The spatial dimension of these spillovers is confirmed by many studies establishing a positive relationship between spatial concentration and activity. For example, for the US, 
Ciccone and Hall (1996) find, from work on US states, that doubling employment density raises labor productivity by $6 \%$. A recent survey by Rosenthal and Strange (2003) reports a consensus view that doubling city size increases productivity by around 3-8\%. Authors who have tried to find the spatial range of such effects find that information spillovers attenuate rapidly over space (for example Jaffe and others 1993). Face-to-face communications remain important, despite technological changes (Gasper and Glaeser 1998).

As for the sectoral spread of spillovers, there is a long-standing debate in the economic geography literature between the relative importance of 'Jacob's externalities' and 'Marshall-Arrow-Romer (MAR) externalities'. The former derive from the diversity of a city, the argument being that innovation and creativity are stimulated by serendipitous interaction in a large and diverse economic environment, such as New York City. By contrast, MAR externalities are knowledge spillovers within narrowly defined sectors, as information on how to produce is transmitted from firm to firm. Detailed empirical studies of productivity spillovers in developing countries confirm the importance of MAR externalities. The positive dependence of productivity on employment levels in the same city and industry has been found by studies for a number of countries (e.g. for the US and Brazil, Henderson 1988; Indonesia, Henderson and Kuncoro 1996; and Korea, Henderson Lee and Lee 2001).

We should note that acquisition and spread of knowledge are important in selling as well as in production. Roberts and Tybout (1997) establish the importance of learning effects in firms export behaviour, and Evenett and Venables (2003), using a fine commodity and geographical disaggregation, show that learning to export also has a destination specific component.

\section{Structural Change in India}

One key objective of this paper is to argue that evidence building at the microeconomic level 
should form the basis of policy formulation on what drives structural change and growth. In this section we focus on one country, India, to illustrate this process in action. Our evidence base remains incomplete. Nonetheless the work we describe illustrates how microeconomic analysis at the sub-national level is beginning to provide the detail on what is important at the local level. It is this detail, which is directly useful to policy makers.

The basic pattern of structural change in India is shown in Figure 3 where we graph real agricultural and non-agricultural output per capita over the 1960-1997 period for the 16 main states of India. Agricultural output per capita remained relatively flat over the period. Economic growth was driven in large part by the rise in non-agricultural output. In 1960 average real state non-agricultural and agricultural output per capita were of similar magnitudes at Rs. 406 and Rs. 425 respectively. By 1997, non-agricultural output at Rs. 2,814 was more than double agricultural output (Rs. 1,266). The pattern of markedly different across states. A similar picture emerges in Figure 4 when we examine manufacturing, which is often seen as the engine of structural change..$^{5}$ Certain states -- Andhra Pradesh, Gujarat, Haryana, Karnataka, Punjab, Tamil Nadu and Maharashtra -- show rapid growth in registered and unregistered manufacturing, while states like Assam, Bihar, Jammu and Kashmir, Kerala, Uttar Pradesh and West Bengal display relative stagnation (albeit from different base levels).

And these differences in economic performance have profound consequences for welfare. India is unusual amongst developing countries in having carried out household expenditure surveys on a regular basis since the 1950s which allows consistent and comparable poverty series to be constructed (see Ozler, Datt and Ravallion, 1996). In Figure 5 we graph rural and urban poverty headcounts (which capture the percentage of the rural and urban population in poverty) for the 16 main Indian states across the 1958-2000 period.

\footnotetext{
${ }^{5}$ Manufacturing in India is divided into a registered or organized sector (which is regulated, and covers firms with employment levels above 10 with electricity and above 20 without) and an unregistered or unorganised sector (which covers firms below these thresholds).
} 
Comparing Figures 3, 4 and 5 what is striking is that states which experienced rapid structural change also experienced faster rural and urban poverty reduction. In short, structural change and growth appear to matter for poverty reduction. ${ }^{6}$ Simple regression analysis helps to bring this point home. In Table 1 we show regressions of poverty measures on output per capita measures using panel data on the 16 main Indian states for the 1958-2000 period. Column (1) shows that increases in the levels of non-agricultural output are associated with significant falls in overall poverty. In contrast, changes in agricultural output do not affect poverty. We find a similar pattern when we break poverty into its urban and rural components in columns (2) and (3) - it is the growth of non-agricultural output which is exerting a significant effect on urban and rural poverty. In columns (4) and (5) we look at the influence of registered and unregistered manufacturing. ${ }^{7}$ In column (4) we see that increases in per capita registered manufacturing output reduce urban but not rural poverty. This makes sense, as these larger firms are located mainly in urban areas. In contrast, increases in output from firms in the unregistered manufacturing sector is significantly negatively associated with rural poverty but not urban poverty (see column (5)). The entry and growth of small businesses is important for explaining the pattern of rural poverty reduction.

We have established that structural change matters for economic growth and poverty reduction in India. We now turn to the question of which institutions and policies account for different rates of structural change across Indian states. We focus, in particular, on manufacturing. The fact that states, within a centrally planned economy, performed so differently in terms manufacturing is striking (see Figure 4). Much of the literature so far has

\footnotetext{
${ }^{6}$ Using Indian state level data Ravallion and Datt (1996) have established a robust link between income growth and poverty reduction. They find that the elasticity of the incidence of poverty with respect to net domestic product per capita was -0.75 for the period 1958 1991. This figure is close to the elasticity of -0.76 which Besley and Burgess (2003b) find using cross-country data for developing economies.

${ }^{7}$ Over the period the registered sector makes up about 9 percent of state output and the unregistered sector 5 percent.
} 
focused on whether the Indian industrial strategy, which involved extensive use of industrial licensing and tariff and non-tariff barriers, led Indian manufacturing to perform poorly relative to other countries in particular those in East Asia (Bhagwati and Desai 1970, and Bhagwati and Srinivasan 1975). ${ }^{8}$ Nationwide policies, however, have limited scope to explain the marked cross-state variation in manufacturing performance that we observe in Figure 4.

To understand these patterns we need to focus on state specific policies and conditions. We examine three examples of research on how $1^{\text {st }}$ advantage factors and the interplay between $1^{\text {st }}$ advantage and $2^{\text {nd }}$ advantage factors determine the pattern of manufacturing growth in India. These examples illustrate how the framework we have developed can be used build up a microeconomic evidence base on what matters.

\section{Example [1]: $1^{\text {st }}$ advantage: labor regulation and registered manufacturing}

Labor regulations have been identified as an important element of the investment climate in India (Stern, 2001; Dollar, Iarossi and Mengitsae, 2001, Sachs et al, 1999). Besley and Burgess (2002) examine whether labor regulation is an important source of $1^{\text {st }}$ advantage which could help explain differences in manufacturing performance across Indian states. To do this they exploit two key facts: (i) labor regulations only apply to firms in the registered manufacturing sector, and (ii) the Indian constitution empowers state governments to amend central legislation. The main piece of central legislation is the Industrial Disputes Act of 1947. This Act has been extensively amended by state governments during the postIndependence period. Besley and Burgess (2002) read the text of each amendment and coded each as pro-worker $(+1)$, neutral $(0)$ or pro-employer $(-1)$. The pattern of change across Indian

\footnotetext{
${ }^{8}$ Between 1960 and 1995, manufacturing as a share of GDP grew from 9 percent to 24 percent of GDP in Indonesia, 8 percent to 26 percent in Malaysia and 12.5 percent to 28 percent in Thailand. In contrast, manufacturing output in India constituted 13 percent of GDP in 1960 but grew to only 18 percent of GDP by 1995. Source: World Development. Indicators.
} 
states is shown in Figure 6 where it is apparent that the direction of regulation varies across states and time.

Besley and Burgess (2002) then check whether the pattern of regulatory changes shown in Figure 6 affects the pattern of manufacturing development shown in Figure 4. Column (1) of Table 2 shows that moving in a pro-worker direction is associated with lower per capita manufacturing output levels. This effect is accounted for by the fact that proworker labor regulation led to less output in registered manufacturing (column (2)). Investment in this sector is lower in states with more pro-worker labor regulation. Column (3) shows that the effect goes the other way for unregistered manufacturing. That is, states with more pro-worker labor regulations tend to have larger informal manufacturing sectors. This makes sense as where workers are able to extract more of the rents from production in registered sector, capitalists will prefer to remain in the unregistered sector where labor has no power. In columns (4) and (5) we see that regulating in a pro-worker direction is also associated with increases in urban poverty but does not affect rural poverty. This reflects the fact that the adverse effects of labor regulation are mainly being felt in the registered sector which is found primarily in urban areas. These results suggest that attempts to redress the balance of power between capital and labor can end up hurting the poor.

As Besley and Burgess (2002) show, the policy choices of state governments in India as regards labor regulation have strongly affected manufacturing performance. $1^{\text {st }}$ advantage factors like regulation which are, in part, under the control of sub-national governments will have a strong bearing on whether or not manufacturing develops in areas under their jurisdiction. And this in turn will have welfare consequences for citizens in those regions. It is important to note that the large differences in manufacturing performance were present well before liberalization in $1991 .^{9}$ This suggests that countries or regions wishing to develop

\footnotetext{
${ }^{9}$ Besley and Burgess (2002) restrict their econometric analysis to the 1958-1992 period in
} 
manufacturing must pay attention to the $1^{\text {st }}$ advantage factors which affect the business climate which firms face and not only to the trade regime. The institutional environment affects the investment and location decisions that entrepreneurs make.

\section{Example [2]: $1^{\text {st }}$ advantage: rural banks and unregistered manufacturing}

Our focus this far has been on the registered manufacturing sector. The majority of individuals in low income countries, however, do not have the choice of working in a factory. This is particularly the case for residents in rural areas. For them the relevant choice might be between remaining in agriculture or starting a small business. These new activities are typically more productive than basic agriculture and thus encourage both growth and poverty reduction. Understanding which factors drive structural change by facilitating the emergence of small businesses is a key challenge.

Burgess and Pande (2003) try to make some inroads into this issue by evaluating whether a massive rural bank branch expansion program in India affected structural change and growth in India. Over the 1961-2000 period more than 30,000 new branches were opened in rural areas. The rationale for the program was simple. The government identified lack of access to finance as a key reason why growth was stagnant and poverty persistent in rural areas. The failure of banks to enter rural areas was seen as a brake on entrepreneurship and the emergence of new activities. To address this, the Indian central bank first nationalized commercial banks in 1969 and then imposed a license rule in 1977 which stated that for each branch opened in a banked location (typically urban) banks had to open four branches in unbanked locations (typically rural). This rule was removed in 1990 and branch building in rural areas came to a halt. As a result of the imposition of the 1:4 rule, states which had fewer banks per capita before the program in 1961 received more bank branches between 1977 and

order to better identify the impact of domestic state level policies. 
1990 leading to both a reduction and an equalization in population per bank branch. Entrepreneurs, small businessmen and agriculturalists were explicitly targeted in the mandated lending practices of banks. The program is an example of government targeting a key $1^{\text {st }}$ advantage factor, access to capital, as a means of encouraging the spread of new economic activities across rural India.

To evaluate the program Burgess and Pande (2003) use these 1977 and 1990 trend breaks in the relationship between initial financial development and rural branch expansion attributable to license regime shifts as instruments for the number of branches opened in the rural unbanked locations. Some results are contained in Table 3. In column (1) we see that rural branch expansion is associated with higher output per capita. This was due to rural branch expansion driving up non-agricultural output. Agricultural output, in contrast, was unaffected. Columns (2) and (3) show that the impact on manufacturing was felt mainly in the unregistered sector. Column (3) suggests that the arrival of banks in rural areas helped people to start and expand small businesses. By addressing a key $1^{\text {st }}$ advantage factor the (albeit forced) entry of banks is seen to have been a spur for entrepreneurship and structural change. In contrast, registered manufacturing which is located mainly in urban areas was unaffected (column (2)). In column (4) we see that the structural change engendered by rural branch expansion had positive consequences in terms of reducing rural poverty. Urban poverty, in contrast, is unaffected (column (5)).

This example brings home how a $1^{\text {st }}$ advantage factor, access to finance, may be critical in enabling poor, rural residents to begin new economic activities. The arrival of rural banks in rural India enabled people to take on new production and employment activities and to exit poverty. The results highlight how important access to finance is for encouraging entrepreneurship, structural change and growth. 
Example [3]: interplay between $1^{\text {st }}$ and $2^{\text {nd }}$ advantage: technological capability and trade liberalization

But how do $2^{\text {nd }}$ advantage factors which are intrinsic to firms and industries interact with $1^{\text {st }}$ advantage factors which affect the environment in which firms function? We have argued that it is the interplay of factors which is critical to understanding modern economic growth. Such interactions are difficult to study empirically as $2^{\text {nd }}$ advantage factors are themselves endogenous.

One way in which we can get some purchase on this issue is to look at how the technological capability of firms or industries affects how they respond to a liberalization shock. That is, in line with the theory in section 3 - we might expect firms in the same industry to respond differently to the threat of entry depending on how competitive they are with the new firms and products. How firms respond will in part depend on the technological choices they have made in the past. Firms that are close to the technological frontier are in a better position to compete with new firms and products. They may respond by investing in new technology to retain existing markets and to benefit from increased access to new markets. In contrast, investment incentives in laggard firms are likely to be blunted and these firms are likely to be harmed by liberalization. This makes it clear that the responses we see to the same liberalization shock are likely to be heterogeneous across geography and within sectors. Heterogeneity in post-reform performance is also likely to be magnified if the institutional environment in which firms are located varies. That is we can think of interactions between market access and other $1^{\text {st }}$ advantage factors leading to differential performance in two firms which are have identical technological capabilities.

To look at this issue of interplay between $1^{\text {st }}$ and $2^{\text {nd }}$ advantage factors Aghion and others (2003) exploit the fact that India experienced a massive trade liberalization in 1991. This shock was common across firms in the same industry. However, firms in different states 
in the same 3-digit industry varied in terms of their level of pre-reform productivity which can be taken as proxy of technological capability. On dimensions such as labor regulation, the institutional environment in which firms function also varied across Indian states as we studied above.

In Table 4 we report how interactions between the liberalization reform (captured by a dummy variable which switches on in 1991), pre-reform technological capability (captured by the ratio of labor productivity in a 3-digit state-industry relative to the most productive state industry in India) and pre-reform state-level investment climate (captured by the labor regulation measure) affected performance in the registered manufacturing sector in India. We look at these relationships using a panel of 3-digit state-industries for the period 1980-1997. In the first row of Table 4 we see that state-industries with higher pre-reform technological capability (ie, closer to the Indian productivity frontier for that industry) saw greater increases in output, employment, labor productivity and total factor productivity post-reform. This shows that state-industries with greater technological capability benefited more from liberalization. In contrast, laggard state industries which were below median productivity for India experienced below trend rates of increase in output, employment, labor productivity and total factor productivity following liberalization in 1991. Manufacturing performance is therefore a function of the interplay between a $1^{\text {st }}$ advantage factor (market access) and a $2^{\text {nd }}$ advantage factor (technological capability).

In the second row of Table 4 we observe, in line with the results presented in Table 2, that state-industries located in states with more pro-worker labor regulation saw less growth in output, employment, labor productivity and total factor productivity for the 1980-1997 period. This makes it clear that institutional environment (as captured by $1^{\text {st }}$ advantage factors such as labor regulation) in which 3-digit industries function affects how well they perform.

Moreover in the third row of Table 4, where we report results for the interaction 
between labor regulation and liberalization, we observe that the negative impact of proworker regulation is magnified in post liberalization period. That is it is even more damaging in terms of output, employment, labor productivity and total factor productivity growth for state-industries to be located in a pro-worker state when market access is increased. These findings from Aghion and others (2003) emphasize that the initial level of technology and institutional context mattered for whether and to what extent industries and states in India benefited from liberalization.

These findings have interesting implications for policy. First, in line with the theory outlined in section 3 it is clear that the level of productivity pre-reform matters for the post liberalization trajectory. The key importance of the interplay between $1^{\text {st }}$ advantage and $2^{\text {nd }}$ advantage factors has a critical bearing on the pattern of post liberalization growth. This of course begs the question of why levels of productivity were different in different 3-digit industries in different states in the first place. That is beyond the scope of the analysis however it does point to the understanding what determines the industrial capabilities of firms as being a central area of research (see Sutton, 2002). Second, the institutional environment affects the extent to which liberalization will be growth-enhancing. For instance, rigidities in the labor market may limit the positive impact of trade liberalization. The institutional and policy choices that state governments make have a central bearing on the extent to which the regions they govern will benefit or not from liberalization. Third, liberalization may have adverse effects on industries and regions that are initially less developed. This may call for complementary measures to offset the negative distributional consequences of reforms, e.g., investment in infrastructure and support for knowledge acquisition in backward areas.

\section{Conclusions}

Establishing the factors that drive structural growth has always been central to development 
economics. As growth theory has developed and disaggregated data have become available, this work has been moving in a microeconomic direction. Some broad correlations are emerging in new cross-country work that tries to explain the very different growth experiences of countries. These serve as useful signposts for more detailed microeconomic work though we are at an early stage in that process. For example, though there may be some consensus that access to finance matters for entrepreneurs, it is unclear how such access should be provided (e.g. private banks, development banks, microfinance). And what is appropriate may depend on the type of business and how developed the legal system and other institutions are.

The microeconomic approach described in this paper represents the frontier for identifying the $1^{\text {st }}$ advantage pre-conditions for growth. This approach based on careful building of microeconomic evidence has become standard in developed economies and is now taking off in research on low-income countries. There is a growing consensus that evidence building via evaluation of policy and institutional reforms represents the best approach for identifying what works. The $1^{\text {st }}$ advantage examples we provide from India illustrate this process at work.

But, as this paper makes plain, identifying sources of $1^{\text {st }}$ advantage is not the whole story. The spatial/sectoral pattern of modern economic growth suggests that it is the result of a complex interaction of $1^{\text {st }}$ advantage factors and what we call $2^{\text {nd }}$ advantage factors. These factors, which include technological capabilities, technological spillovers, market linkages and networks, are the results of investment and location decisions made by entrepreneurs. The externalities that they create shapes future growth. As the example from India brings out, it is the interaction between $1^{\text {st }}$ advantage and $2^{\text {nd }}$ advantages which determine where and in which sectors growth takes place. This observation brings into sharp relief the fact that modern economic growth is the result of interactions between institutions and organizations. 
Understanding the factors that drive the technological, investment and location decisions of firms is therefore central to understanding modern economic growth. These decisions will themselves be a function of institutions and other $1^{\text {st }}$ advantage factors that make the empirical study of growth challenging.

Two key policy lessons emerge from our analysis. First, in the absence of $1^{\text {st }}$ advantage elements, rapid structural change and growth are unlikely to take place. Much recent work is therefore focussed on uncovering the microeconomic roots of backwardness. Second, ensuring that $1^{\text {st }}$ advantage elements are present is not a guarantee that rapid economic growth will take place in a given location. Consideration of $2^{\text {nd }}$ advantage factors, at the microeconomic level, is thus central to understanding economic growth. And here our knowledge base is extremely thin.

The paper constitutes a modest step toward understanding which factors drive growth at the microeconomic level. Given the strong links between innovation, growth and poverty reduction, few endeavours in economics are more important. 


\section{References}

The word "processed" describes informally reproduced works that may not be commonly available in libraries.

Acemoglu, Daron, Simon Johnson, and James A. Robinson. 2001. "The Colonial Origins of Comparative Development: An Empirical Investigation.” American Economic Review 91(5): 1369-1401.

Aghion, Philippe, and Peter Howitt. 1998. Endogenous Growth Theory. Cambridge, MA: MIT Press. . 2003. "Growth with Quality Improving Innovations.” Harvard University, Cambridge, MA. Processed.

Aghion, Philippe, Robin Burgess, Stephen Redding, and Fabrizio Zilibotti. 2003. "The Unequal Effects of Liberalization: Evidence from India." London School of Economics, London. Processed.

Aranya, Rollee. 2002. "Spatial Disparity in the Globalizing City: The Case of the Silicon Plateau Emerging in Bangalore." University of Trondheim, Trondheim, Norway. Processed.

Banerjee, Abhijit, and Andrew Newman. 2003. "Inequality, Growth, and Trade Policy." Massachusetts Institute of Technology, Cambridge, MA. Processed.

Banerjee, Abhijit V., Paul J. Gertler, and Maitreesh Ghatak. 2002. "Empowerment and Efficiency: Tenancy Reform in West Bengal.” Journal of Political Economy 110(2): $239-80$.

Banerjee, Abhijit, Shawn Cole, Esther Duflo, and Leigh Linden. 2003. "Improving the 
Quality of Education in India: Evidence from Three Randomized Experiments." Massachusetts Institute of Technology, Cambridge, MA. Processed.

Besley, Timothy, and Robin Burgess. 2000. "Land Reform Poverty and Growth: Evidence from India." Quarterly Journal of Economics 115(2): 389-430.

Besley, Timothy and Robin Burgess. 2002. "Can Labor Regulation Hinder Economic Performance? Evidence from India.” CEPR Discussion Paper No 3260, Centre for Economic Policy Research, London.

. 2003a. "Court Efficiency and Economic Performance in India." London School of Economics, London. Processed.

. 2003b. "Halving Global Poverty.” Journal of Economic Perspectives 17(3): 3-22.

. 2004. "Can Labor Regulation Hinder Economic Performance? Evidence from India." Quarterly Journal of Economics 119(1): 91-134.

Bhagwati, Jagdish, and Padma Desai. 1970. India: Planning for Industrialization. Delhi: Oxford University Press.

Bhagwati, Jagdish, and T. N. Srinivasan. 1975. Foreign Trade Regimes and Economic Development. Delhi: McMillan.

. 1999. Outward Orientation and Development: Are the Revisionists Right? Discussion Paper no. 806. New Haven, CN: Yale University, Economic Growth Center.

Botero, Juan Carlos, Simeon Djankov, Rafael La Porta, Florencio López-de-Silanes, and Andrei Shleifer. 2003. “The Regulation of Labor.” Working Paper no. 9756. National Bureau of Economic Research, Cambridge, MA.

Burgess, Robin, and Rohini Pande. 2003. "Do Rural Banks Matter? Evidence from the Indian Social Banking Experiment." London School of Economics, London, and Columbia 
University, New York. Processed.

Card, David. 1999. "The Causal Effect of Education on Earnings.” In Orley Ashenfelter and D. Card, eds., Handbook of Labor Economics. Amsterdam: Elsevier.

Chakravorty, S., and S. V. Lall. 2003. "Diversity Matters: The Economic Geography of Industry Location in India." Working Paper no. 3072. World Bank, Washington, D.C.

Chattopadhyay, Raghabendra, and Esther Duflo. 2001. "Women as Policy Makers: Evidence from an India-Wide Randomized Policy Experiment." Massachusetts Institute of Technology, Cambridge, MA. Processed.

Chenery, Hollis B. 1960. "Patterns of Industrial Growth.” American Economic Review 50(4): $624-54$.

Chenery, Hollis B., and Lance J. Taylor. 1968. “Development Patterns: Among Countries and Over Time." Review of Economics and Statistics 50(4): 391-416.

Ciccone, Antonio, and Robert E. Hall. 1996. "Productivity and the Density of Economic Activity." American Economic Review 86(1): 54-70.

Cikurel, Daniel Chiquiar. 2002. "Why Mexico’s Regional Convergence Broke Down.” University of California, San Diego. Processed.

Datt, Gaurav and Martin Ravallion. 2002. "Is India's Growth Leaving the Poor Behind" Journal of Economic Perspectives, 16(3): 89-108.

Demurger, S, J. Sachs, W. Woo, S. Bao, G. Change, and A. Mellinger. 2002. "Geography, Economic Policy, and Regional Development in China.” University of California, Davis. Processed.

Djankov, Simeon, Rafael La Porta, Florencio Lopez-de-Silanes, and Andrei Shleifer. 2002. “The Regulation of Entry." Quarterly Journal of Economics 117(1): 1-37. 
Djankov, Simeon, Edward L. Glaeser, Rafael La Porta, Florencio Lopez de Silanes, and Andrei Shleifer. 2003. "The New Comparative Economics.” Discussion Paper no. 3882. Centre for Economic Policy Research, London

Dollar, David, and Aart Kraay. 2000. "Growth Is Good for the Poor.” Development Research Group, World Bank, Washington, D.C. Processed.

Dollar, David, Giuseppe Iarossi, and Taye Mengistae. 2001. "Investment Climate and Economic Performance: Some Firm Level Evidence from India.” Paper prepared for the Economists' Forum, 3 - 4 May, World Bank, Washington, D.C.

Duflo, Esther. 2001. "Schooling and Labor Market Consequences of School Construction in Indonesia: Evidence from an Unusual Policy Experiment." American Economic Review 91(4): 795-813.

Evenett, Simon, and Anthony J. Venables. 2003. "Export Growth in Developing Countries: Market Entry and Bilateral Trade Flows.” London School of Economics, London. Processed.

Evenson, R. E., and L. E. Westphal. 1995. "Technological Change and Technology Strategy." In Hollis B. Chenery and T. N. Srinivasan, eds., Handbook of Development Economics, vol. 3a. Amsterdam: North-Holland.

Field, Erica. 2002. "Entitled to Work: Urban Property Rights and Labor Supply in Peru." Princeton University, Princeton, NJ. Processed.

Frankel, Jeffrey A., and David Romer. 1999. "Does Trade Cause Growth?” American Economic Review 89(3): 379-99.

Fujita, Masahisa, Paul Krugman, and Anthony J. Venables. 1999. The Spatial Economy: Cities, Regions, and International Trade. Cambridge, MA: MIT Press. 
Gallup, John L., and Jeffrey Sachs (with Andrew Mellinger). 1999. "Geography and Economic Development.” In Boris Pleskovic and Joseph E. Stiglitz, eds., Annual World Bank Conference on Development Economics, 1998. Washington, D.C.: World Bank.

Gasper, J., and E. L. Glaeser. 1998. “ Information Technology and the Future of Cities.” Journal of Urban Economics 43(1): 136-56.

Glaeser, Edward L., Simon Johnson and Andrei Shleifer. 2001. "Coase vs. The Coasians," Quarterly Journal of Economics, 116(3): 853-899.

Glewwe, Paul, Michael Kremer, and Sylvie Moulin. 2000. "Textbooks and Test Scores: Evidence from a Prospective Evaluation in Kenya.” Harvard University, Department of Economics, Cambridge, MA. Processed.

Hall, Robert E., and Chad Jones. 1999. "Why Do Some Countries Produce So Much More Output Per Worker Than Others?” Quarterly Journal of Economics 114(1): 83-116.

Hallward-Driemeier, M., G. Iarossi and K. L. Sokoloff. 2002. "Exports and Manufacturing Productivity in East Asia: A Comparative Analysis with Firm-level Data”. Working Paper no. 8894. National Bureau of Economic Research, Cambridge, MA.

Hausmann, R., and D. Rodrik. 2002. "Economic Development as Self-Discovery.” Working Paper no. 8952. National Bureau of Economic Research, Cambridge, MA.

Henderson, J. V. 1988. Urban Development: Theory, Fact, and Illusion. Oxford, U.K.: Oxford University Press. . 1999. "How Urban Concentration Affects Economic Growth." Policy Research Working Paper no. 2326. World Bank, Washington, D.C.

Henderson, J. V., and A. Kuncoro. 1996. "Industrial Centralization in Indonesia.” World Bank 
Economic Review 10(3): 513-40.

Henderson, J. V., T. Lee, and Y.-J. Lee. 2001. "Scale Externalities in Korea," Journal of Urban Economics 49(3): 479-504.

Henderson, J. V., and H. G. Wang. 2003. "Urbanization and City Growth." Brown University, Providence, RI. Processed.

Hirshman, Albert. 1958. The Strategy of Economic Development. New Haven, CN: Yale University Press.

Hobday, M. 1995. Innovation in East Asia: The Challenge to Japan. Aldershot, U.K.: Edward Elgar.

Holmes, T. J. 1999. "Localisation of Industry and Vertical Disintegration." Review of Economics and Statistics 81(2): 314-25.

Hsieh, Chang-Tai, and Miguel Urquiola. 2002. "When Schools Compete, How Do They Compete? An Assessment of Chile's Nationwide School Voucher Program.” Princeton University, Princeton, NJ. Processed.

Jaffe, A., M. Tratjenberg, and J. V. Henderson. 1993. "Geographic Localization of Knowledge Spillovers as Evidenced by Patent Citations.” Quarterly Journal of Economics 108(3): 577-98.

Johnson, Simon, McMillan, John, and Christopher Woodruff. 2002a. "Courts and Relational Contracting.” Journal of Law, Economics, and Organization 18(1): 221-77. . 2002b. “Property Rights and Finance." American Economic Review 92(5): 1335-1356.

Klien, Shira. 2003. "Human Capital Externalities in India.” London School of Economics, London. Processed.

Kremer, Michael, and Edward Miguel. 2001. "Worms: Education and Health Externalities in 
Kenya." Working Paper no. 8481. National Bureau of Economic Research, Cambridge, MA.

Krueger, Alan B., and Mikael Lindhal. 2001. "Education for Growth: Why and for Whom?" Journal of Economic Literature XXXIX(4): 1101-36.

Krugman, P. 1981. “Trade, Accumulation, and Uneven Development." Journal of Development Economics 8(2): 149-61.

La Porta, Rafael, Florencio Lopez-de-Silanes, Andrei Shleifer, and Robert Vishny. 1997. “The Legal Determinants of Finance.” Journal of Finance 52(3): 1131-1150. . 1998. “Law and Finance.” Journal of Political Economy 106(6): 1113-1155.

Leamer, E. 1984. Sources of Comparative Advantage. Cambridge, MA: MIT Press. . 1987. "Paths of Development in the Three Factor N-Good General Equilibrium Model." Journal of Political Economy 95(5): 961-99.

Levine, Ross. 1998. "The Legal Environment, Banks, and Long-Run Economic Growth.” Journal of Money, Credit, and Banking 30(3): 596-613.

Lewis, W. A. 1954. "Economic Development with Unlimited Supplies of Labour." Manchester School of Economic and Social Studies 22(May): 139-91.

Limao, N., and A. J. Venables. 2001. "Infrastructure, Geographical Disadvantage, Transport Costs, and Trade." World Bank Economic Review 15(3): 451-79.

Lin, Justin Yifu. 1992. "Rural Reforms and Agricultural Growth in China." American Economic Review 82(1): 34-51.

McCulloch, N., L. A. Winters, and X. Cirera. 2002. Trade Liberalization and Poverty: A Handbook. London: Centre for Economic Policy Research. 
McMillan, John, and Christopher Woodruff. 1999. "Interfirm Relationships and Informal Credit in Vietnam.” Quarterly Journal of Economics 114(4): 1285-1320.

. 2002. "The Centrality of Entrepreneurs in Transition Economies." Journal of Economic Perspectives 16(3): 153-70.

Moretti, E. 2003. "Human Capital Externalities in Cities." In V. Henderson and J. Thisse, eds., Handbook of Regional and Urban Economics, Volume 4. New York: Elsevier Science, (forthcoming).

Murphy, K., A. Shleifer, and R. W. Vishny. 1989. "Industrialization and the Big Push." Journal of Political Economy 97(5): 1003-26.

North, Douglass C. 1990. Institutions, Institutional Change, and Economic Performance. Cambridge, U.K.: Cambridge University Press.

Ozler, B., G. Datt, and M. Ravallion. 1996. "A Data Base on Poverty and Growth in India." World Bank, Washington, D.C. Processed.

Pavcnik, N. 2002. “Trade Liberalization, Exit, and Productivity Improvements: Evidence from Chilean Plants.” Review of Economic Studies 69(1): 245-76.

Puga, D., and A. J. Venables. 1999. “Agglomeration and Economic Development: Import Substitution Versus Trade Liberalisation.” Economic Journal 109(455): 292-311.

Qian, Y. 2003. "How Reform Worked in China.” In D. Rodrik, ed., In Search of Prosperity: Analytic Narratives of Economic Growth. Princeton, NJ: Princeton University Press.

Rajan, Raghuram G \& Zingales, Luigi. 1998. "Financial Dependence and Growth,” American Economic Review 88(3): 559-86.

Ravallion, M. and G. Datt. 2002. “Is India's Economic Growth Leaving the Poor Behind?" Journal of Economic Perpectives, 16(3): 89-108. 
Redding, S., and A. J. Venables. 2004. "Economic Geography and International Inequality." Journal of International Economics, 62(1), 53-82.

Roberts, Mark J., and James R. Tybout. 1997. "The Decision to Export in Colombia: An Empirical Model of Entry with Sunk Costs.” American Economic Review 87(4): 54564.

Rodriguez, F., and D. Rodrik. 2000. "Trade Policy and Economic Growth: A Skeptic's Guide to the Cross-National Evidence." In B. Bernanke and K. S. Rogoff, eds., Macroeconomics Annual 2000, MIT Press for NBER, Cambridge, MA.

Rodrik, Dani. 2003. “Growth Strategies.” Harvard University, Cambridge, MA. Processed.

Rosenthal, S. S., and W. C. Strange. 2003. "Evidence on the Nature and Sources of Agglomeration Economies." In V. Henderson and J. Thisse, eds., Handbook of Regional and Urban Economics, Volume 4. New York: Elsevier Science, (forthcoming).

Rostow, W. W. 1960. The Stages of Economic Growth. Cambridge, U.K.: Cambridge University Press.

Sachs, J.D, J. Gallup and A. Mellinger 1999 "Geography and Economic Development” in Annual World Bank Conference on Development Economics 1998, eds B. Pleskovic and J. Stigtlitz, Washington DC: World Bank.

Schott, P. 2003. "One Size Fits All? Heckscher-Ohlin Specialization in Global Production.” American Economic Review 93(2): 686-708.

Shishido, H., and W. Wheaton. 1982. "Urban Concentration, Agglomeration Economies, and the Level of Economic Development." Economic Development and Cultural Change 30(1): 17-30. 
Sokoloff, Kenneth. 1986. "Productivity Growth in Manufacturing in Early Industrialization: Evidence from the American Northeast, 1820-1860." In S. Engerman and R. Gallman, eds., Long Term Factors in American Economic Growth. Chicago: Chicago University Press.

Stern, Nicholas. 2001. A Strategy for Development. Washington DC: World Bank.

Stern, Nicholas. 2003. "Poor People and Economic Opportunity: The Dynamics of Development." Munich Lectures in Economics, November 19, 20, and 21, 2002. Centre for Economic Studies, Ludwig-Maximilians-Universität, Munich.

Sutton, John. 2002. "Rich Trades, Scarce Capabilities: Industrial Development Revisited." Economic and Social Review 33(1): 1-22.

Trefler, D., and S. Zhu. 2001. "Ginis in General Equilibrium: Trade, Technology, and Southern Inequality." Working Paper no. 8446. National Bureau of Economic Research, Cambridge, MA.

Venables, A. J. 2003. "Spatial Disparities in Developing Countries: Cities, Regions, and International Trade. London School of Economics, London. Processed.

Williamson, J. G. 1965. "Regional Inequality and the Process of National Development." Economic Development and Cultural Change 13(4): 3-45.

Yeats, A. 1998. "Just How Big Is Global Production Sharing.” Policy Research Working Paper no. 1871. World Bank, Washington, D.C.

Young, A. 1991. "Learning by Doing and the Dynamic Effects of International Trade." Quarterly Journal of Economics 106(2): 369-406. 
Employment in each location, $n_{i}$

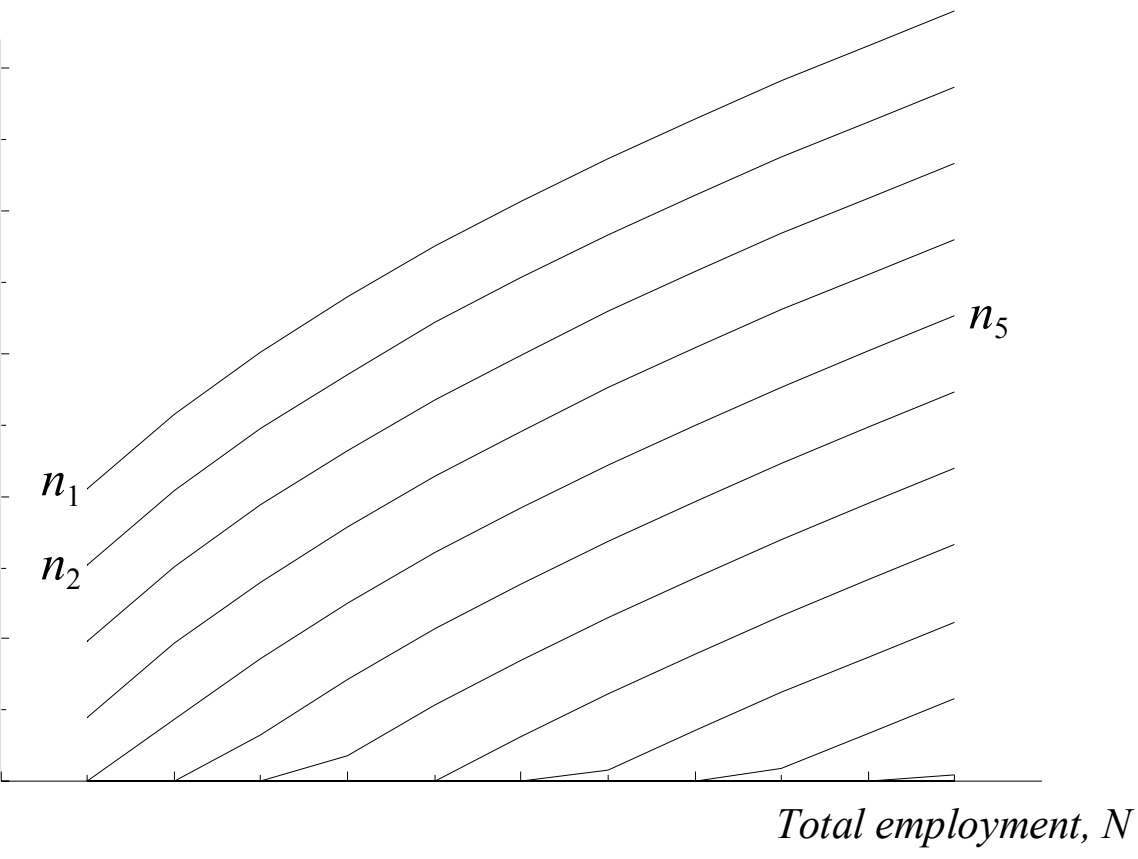

Figure 1: Development without 2nd advantage



Figure 2: Development with 1st and 2nd advantage 
- agricultural output per capita

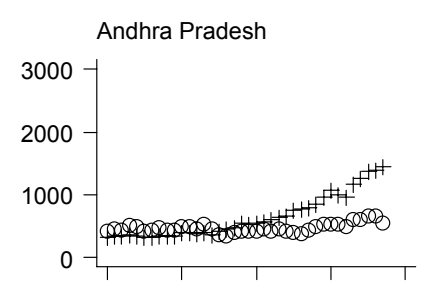

Haryana

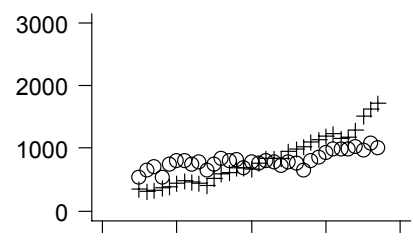

Madhya Pradesh

3000

2000

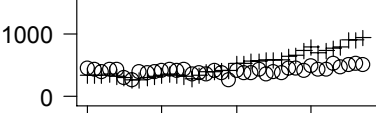

Rajasthan

3000

2000

1000

-

$1960 \quad 1970 \quad 1980 \quad 19902000$
Assam

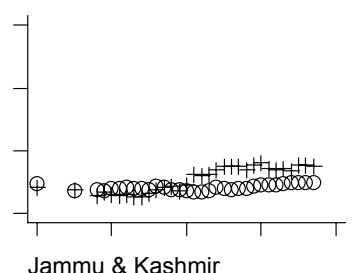

Jammu \& Kashmir

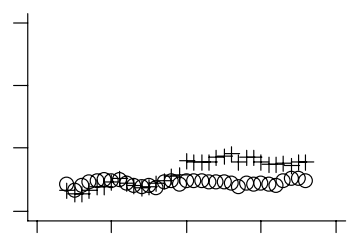

Maharashtra

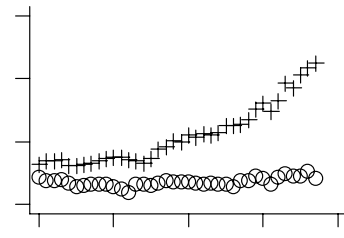

Tamil Nadu



non-agricultural output per cap

Bihar



Karnataka

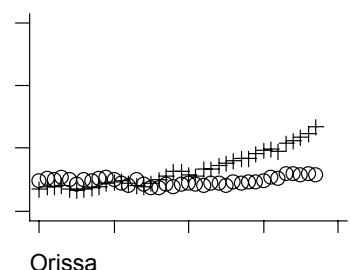

Orissa

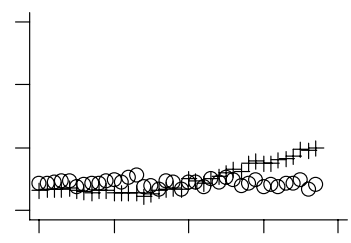

Uttar Pradesh

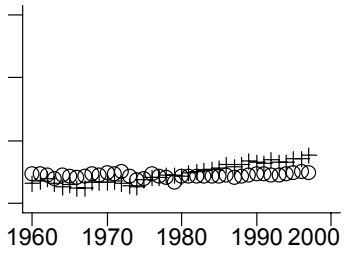

Gujarat

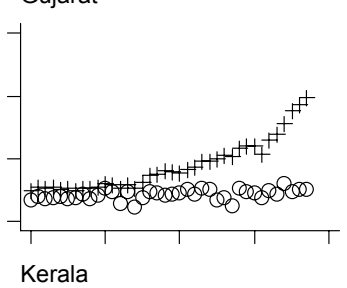

Kerala

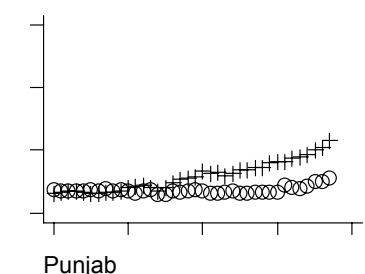

Punjab



West Bengal

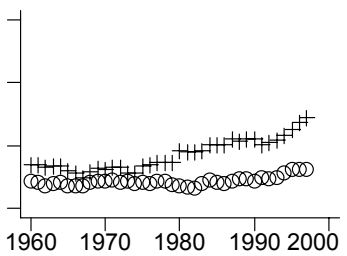

Figure 3: Output Per Capita In India 
- $\quad$ registered manufacturing output
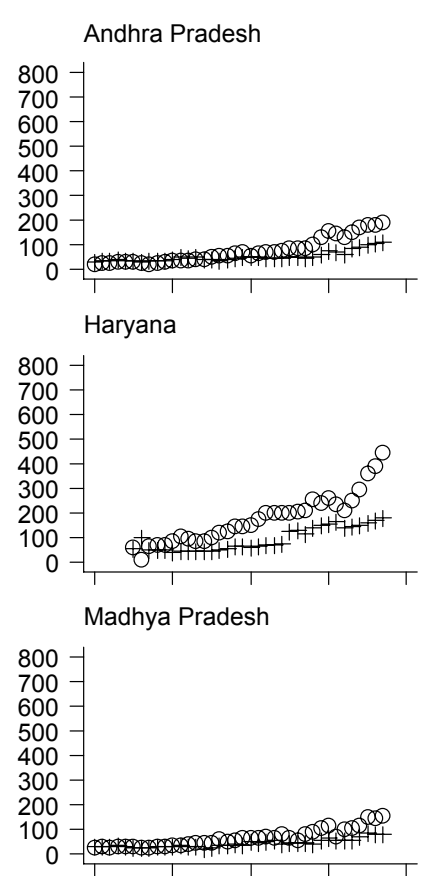

Rajasthan

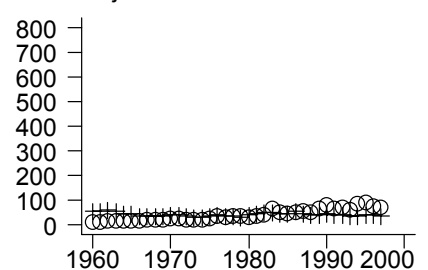

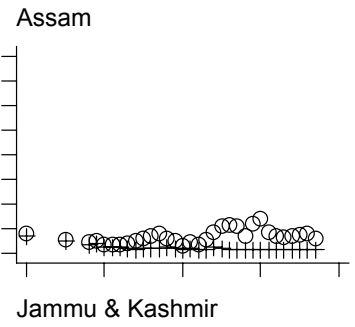

Jammu \& Kashmir

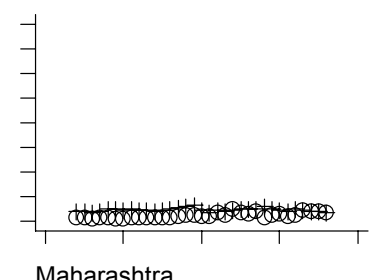

Maharashtra

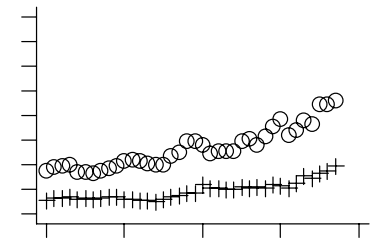

Tamil Nadu



$+\quad$ unregistered manufacturing outp

Bihar



Karnataka
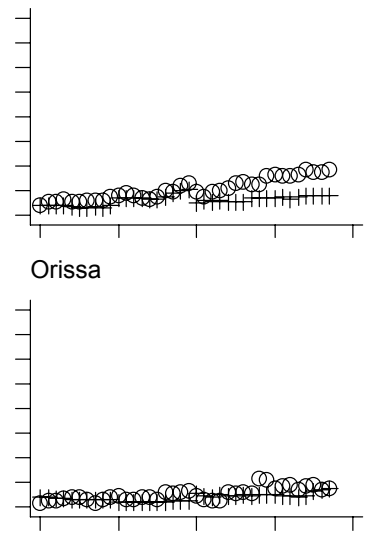

Uttar Pradesh

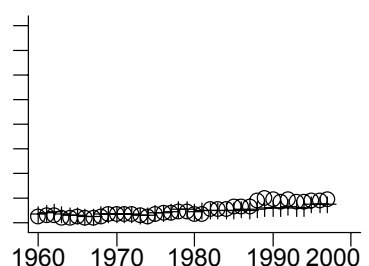

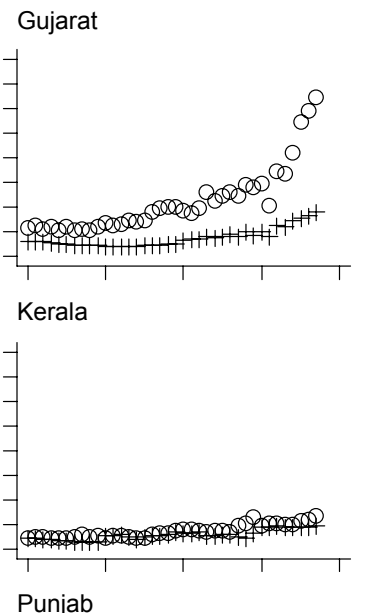

Punjab

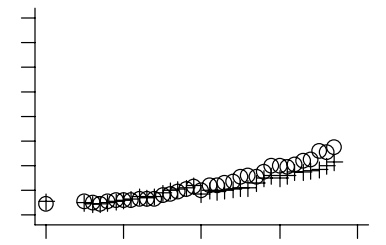

West Bengal

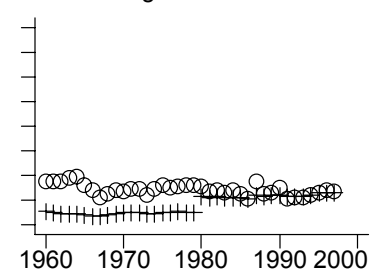

Figure 4: Manufacturing Output Per Capita in India 
- rural poverty headcount



Haryana

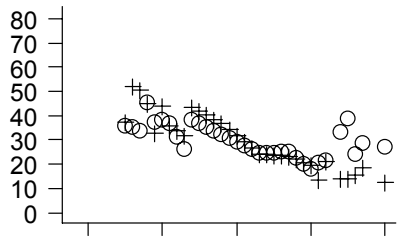

Madhya Pradesh

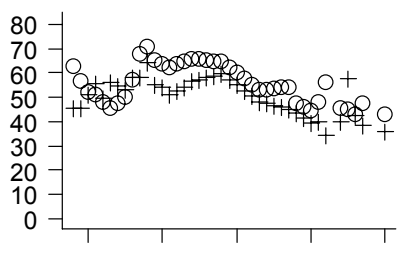

Rajasthan

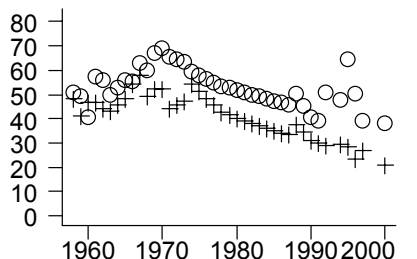

Assam

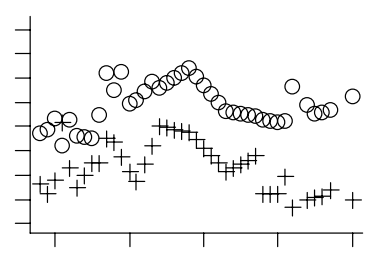

Jammu \& Kashmir

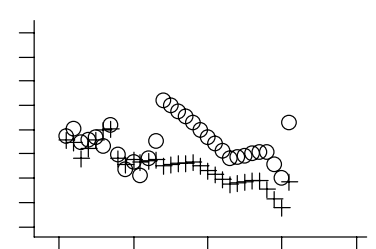

Maharashtra

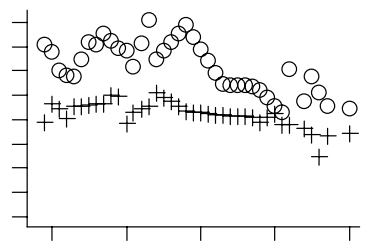

Tamil Nadu

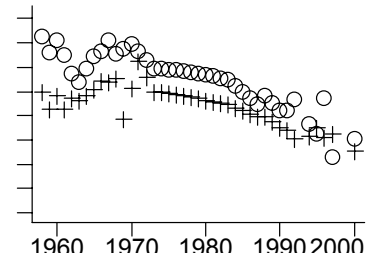

$+\quad$ urban poverty headcount

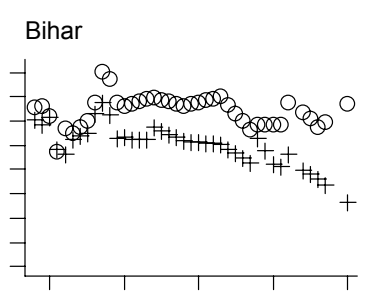

Karnataka

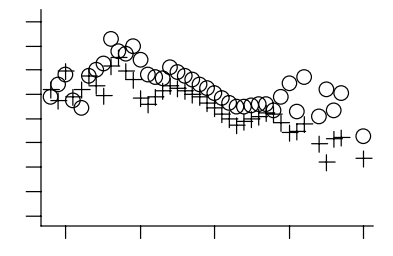

Orissa

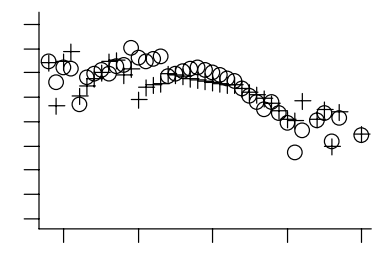

Uttar Pradesh

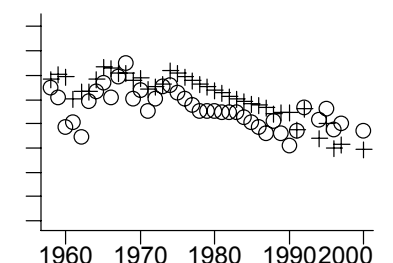

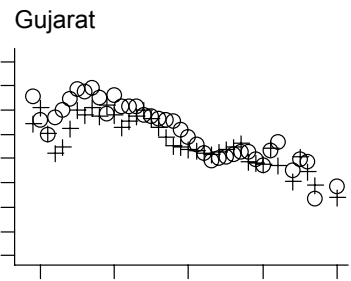

Kerala

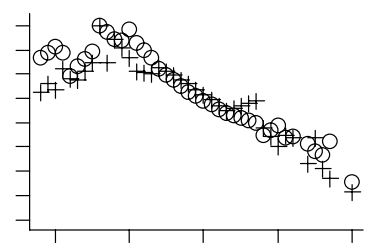

Punjab

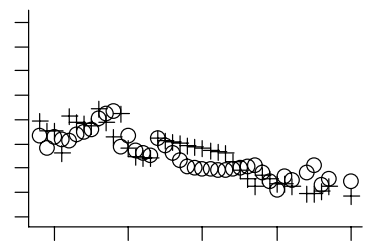

West Bengal

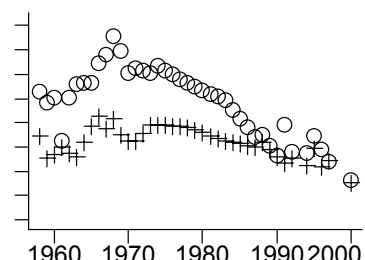

\section{Figure 5: Rural and Urban Poverty in India}



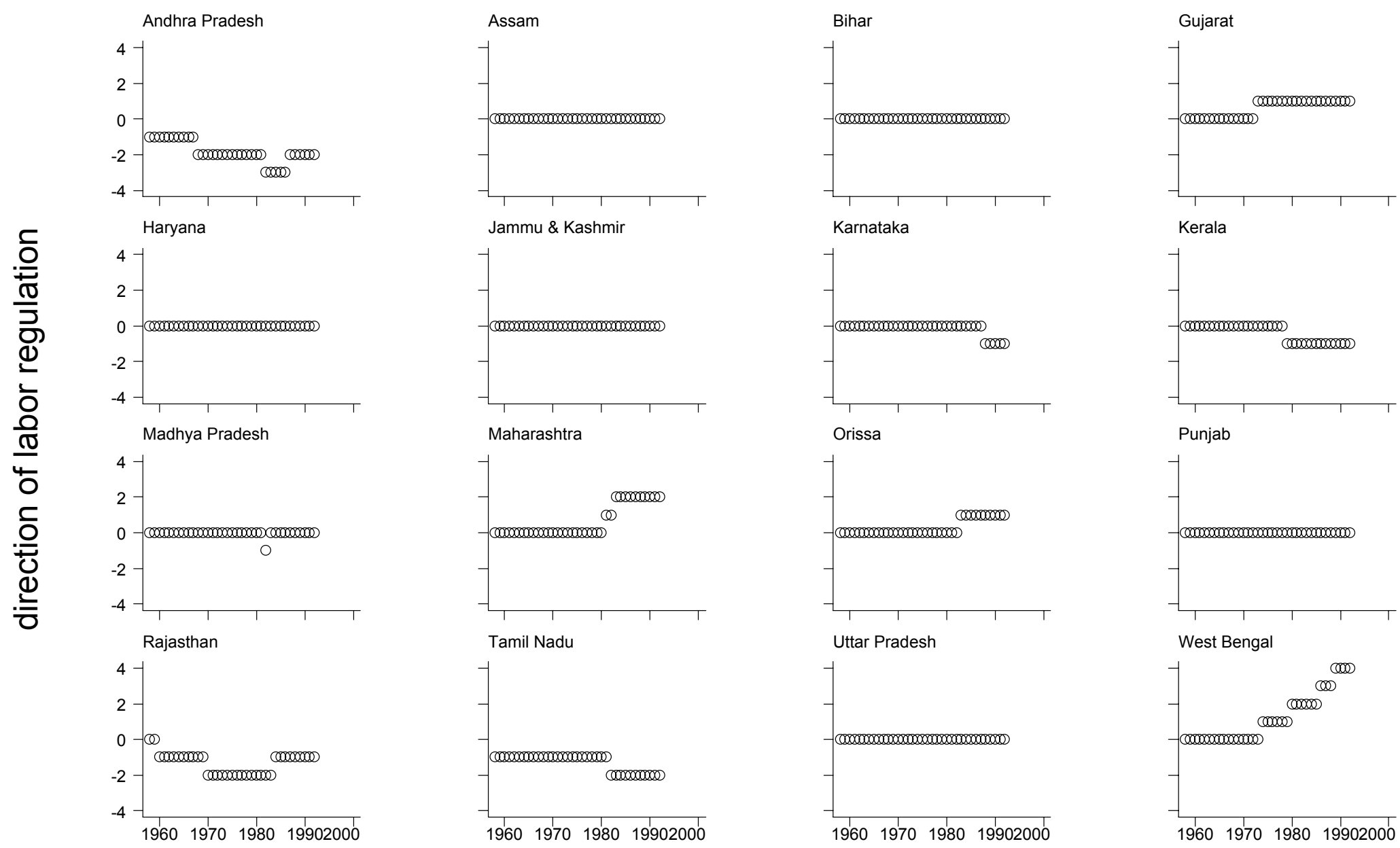

Karnataka

Kerala
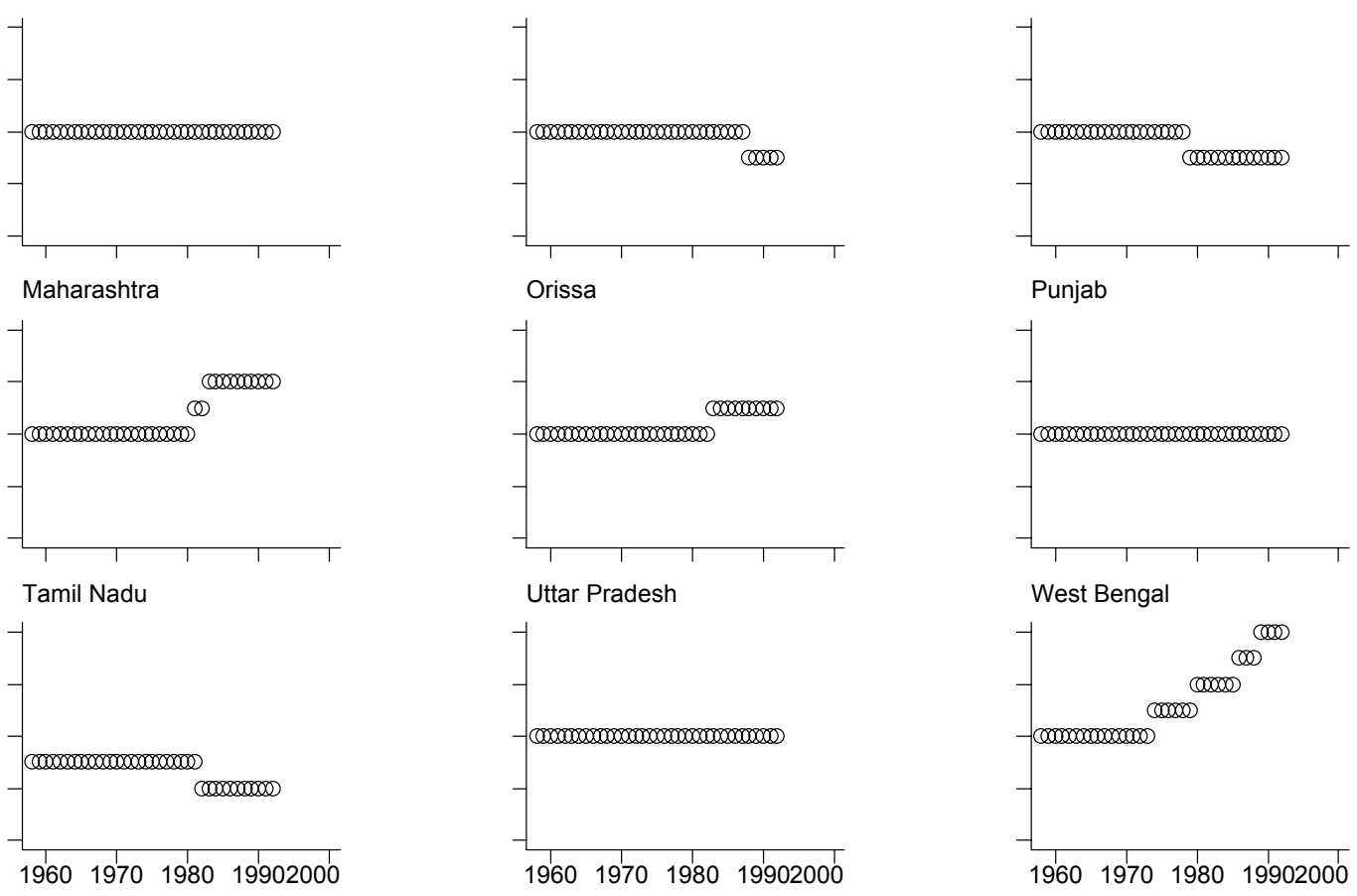

Figure 6: Labour Regulation in India 
Table 1: Poverty and Output in India

\begin{tabular}{|c|c|c|c|c|c|}
\hline & (1) & (2) & (3) & (4) & (5) \\
\hline & $\begin{array}{c}\text { Total } \\
\text { poverty } \\
\text { headcount }\end{array}$ & $\begin{array}{c}\text { Urban } \\
\text { poverty } \\
\text { headcount }\end{array}$ & $\begin{array}{c}\text { Rural } \\
\text { poverty } \\
\text { headcount }\end{array}$ & $\begin{array}{c}\text { Urban } \\
\text { poverty } \\
\text { headcount }\end{array}$ & $\begin{array}{c}\text { Rural } \\
\text { poverty } \\
\text { headcount }\end{array}$ \\
\hline Model & OLS & OLS & OLS & OLS & OLS \\
\hline $\begin{array}{c}\text { Log ag output } \\
\text { pc }\end{array}$ & $\begin{array}{c}4.22 \\
(1.37)\end{array}$ & $\begin{array}{c}1.46 \\
(0.48)\end{array}$ & $\begin{array}{c}4.60 \\
(1.27)\end{array}$ & $\begin{array}{c}1.53 \\
(0.56)\end{array}$ & $\begin{array}{c}3.49 \\
(0.91)\end{array}$ \\
\hline $\begin{array}{l}\text { Log non-ag } \\
\text { output pc }\end{array}$ & $\begin{array}{c}-16.27 * * * \\
(3.00)\end{array}$ & $\begin{array}{c}-9.34 * * * \\
(2.42)\end{array}$ & $\begin{array}{c}-16.18^{* * *} \\
(2.23)\end{array}$ & & \\
\hline $\begin{array}{l}\text { Log reg manu } \\
\text { output pc } \\
\text { Log unreg } \\
\text { manu output } \\
\text { pc }\end{array}$ & & & & $\begin{array}{c}-4.51 * * * \\
(3.20) \\
-1.91 \\
(1.65)\end{array}$ & $\begin{array}{c}-0.40 \\
(0.15) \\
-5.99 * * * \\
(2.52)\end{array}$ \\
\hline State effects & YES & YES & YES & YES & YES \\
\hline Year effects & YES & YES & YES & YES & YES \\
\hline Adjusted $\mathrm{R}^{2}$ & 0.83 & 0.88 & 0.79 & 0.89 & 0.79 \\
\hline Observations & 318 & 318 & 318 & 318 & 318 \\
\hline
\end{tabular}

Table 2: Labour Regulation and Manufacturing Output in India

\begin{tabular}{cccccc}
\hline \hline & $(1)$ & $(2)$ & $(3)$ & $(4)$ & $(5)$ \\
\hline & $\begin{array}{c}\text { Log total } \\
\text { manu output } \\
\text { pc }\end{array}$ & $\begin{array}{c}\text { Log reg } \\
\text { manu output } \\
\text { pc }\end{array}$ & $\begin{array}{c}\text { Log unreg } \\
\text { manu output } \\
\text { pc }\end{array}$ & $\begin{array}{c}\text { Urban } \\
\text { poverty } \\
\text { headcount }\end{array}$ & $\begin{array}{c}\text { Rural } \\
\text { poverty } \\
\text { headcount }\end{array}$ \\
\hline Model & OLS & OLS & OLS & OLS & OLS \\
\hline Labour & $-0.073^{* *}$ & $-0.186^{* * *}$ & $0.086^{* *}$ & $2.288^{* * *}$ & -0.821 \\
regulation [t-1] & $(2.05)$ & $(2.90)$ & $(2.46)$ & $(3.31)$ & $(0.48)$ \\
State effects & YES & YES & YES & YES & YES \\
Year effects & YES & YES & YES & YES & YES \\
Adjusted R & 0.93 & 0.93 & 0.75 & 0.89 & 0.80 \\
Observations & 509 & 508 & 509 & 547 & 547 \\
\hline \hline
\end{tabular}

Source Besley and Burgess (2002). Standard errors adjusted for clustering by state. Absolute t statistics in parenthesis.*significant $10 \%$ level, ** significant 5\% level, ***significant $1 \%$ level. Registered and unregistered manufacturing output are in log real per capita terms. Poverty headcount is the percentage of the population below the official Indian poverty lines which are separately defined for rural and urban areas. State amendments to the Industrial Disputes Act are coded 1=pro-worker, $0=$ neutral, $-1=$ pro-employer and then cumulated over the period to generate the labor regulation measure. The data are for the sixteen main states for the period $1958-1992$. 
Table 3: Rural Banks and Manufacturing Output in India

\begin{tabular}{|c|c|c|c|c|c|}
\hline & $\overline{(1)}$ & (2) & (3) & (4) & $\overline{(5)}$ \\
\hline & $\begin{array}{c}\text { Log total } \\
\text { manu output } \\
\text { pc }\end{array}$ & $\begin{array}{c}\text { Log reg } \\
\text { manu output } \\
\text { pc }\end{array}$ & $\begin{array}{c}\text { Log unreg } \\
\text { manu output } \\
\text { pc }\end{array}$ & $\begin{array}{c}\text { Rural } \\
\text { poverty } \\
\text { headcount }\end{array}$ & $\begin{array}{c}\text { Urban } \\
\text { poverty } \\
\text { headcount }\end{array}$ \\
\hline Model & IV & IV & IV & IV & IV \\
\hline $\begin{array}{c}\text { No. branches } \\
\text { opened in rural } \\
\text { unbanked } \\
\text { locations pc }\end{array}$ & $\begin{array}{l}-0.15^{*} \\
(2.10)\end{array}$ & $\begin{array}{c}0.04 \\
(0.57)\end{array}$ & $\begin{array}{l}0.28^{*} \\
(1.85)\end{array}$ & $\begin{array}{c}-5.02^{* *} \\
(2.14)\end{array}$ & $\begin{array}{l}-0.82 \\
(0.92)\end{array}$ \\
\hline State effects & YES & YES & YES & YES & YES \\
\hline Year effects & YES & YES & YES & YES & YES \\
\hline Adjusted $\mathrm{R}^{2}$ & 0.94 & 0.94 & 0.81 & 0.75 & 0.92 \\
\hline Observations & 579 & 579 & 579 & 627 & 627 \\
\hline \multicolumn{6}{|c|}{$\begin{array}{l}\text { Source: Burgess and Pande (2003). Standard errors adjusted for clustering by state. Absolute t statistics in parenthesis. *ignificant } 10 \% \\
\text { level, ** significant } 5 \% \text { level, } * * * * \text { *ignificant } 1 \% \text { level. Registered and unregistered mannfacturing output are in log real per capita terms. } \\
\text { Poverty headcount is the percentage of the population below the official Indian poverty lines which are separately defined for rural and urban } \\
\text { areas. The number of branches in rural unbanked locations is normalized by } 1961 \text { population. The two instruments for this variable are the } \\
\text { number of banked locations in } 1961 \text { per capita interacted with (i) an indicator variable which equals one if the year }>1976 \text { and a post } 1976 \\
\text { time trend (ii) an indicator variable which equals one if the year }>1989 \text { and a post } 1989 \text { time trend respectively. Sample is a panel of the } 16 \\
\text { main Indian states for the period } 1961-2000 \text {. }\end{array}$} \\
\hline
\end{tabular}

Table 4: Technological Capability, Liberalization and Manufacturing Performance in India

\begin{tabular}{|c|c|c|c|c|}
\hline & (1) & (2) & (3) & $\begin{array}{l}(4) \\
\end{array}$ \\
\hline & $\begin{array}{l}\text { Log total reg } \\
\text { manu output }\end{array}$ & $\begin{array}{l}\text { Log reg manu } \\
\text { employment }\end{array}$ & $\begin{array}{c}\text { Log reg man } \\
\text { output per } \\
\text { worker }\end{array}$ & $\begin{array}{l}\text { Log total factor } \\
\text { productivity }\end{array}$ \\
\hline Model & IV & IV & IV & IV \\
\hline Pre-reform tech & $0.439 * * *$ & $0.211 * * *$ & $0.228 * * *$ & $0.159 * * *$ \\
\hline Labour regulation & $\begin{array}{c}-0.090 * * * \\
(3.88)\end{array}$ & $\begin{array}{c}-0.035^{*} \\
(1.69)\end{array}$ & $\begin{array}{c}-0.055^{* *} \\
(1.98)\end{array}$ & $\begin{array}{c}-0.070 * * * \\
(3.13)\end{array}$ \\
\hline $\begin{array}{c}\text { Labour regulation } \\
\text { *reform }^{\text {refor }}\end{array}$ & $\begin{array}{c}-0.061 * * * \\
(4.38)\end{array}$ & $\begin{array}{c}-0.052 * * * \\
(4.39)\end{array}$ & $\begin{array}{l}-0.010 \\
(0.17)\end{array}$ & $\begin{array}{c}-0.036 * * * \\
(4.12)\end{array}$ \\
\hline $\begin{array}{l}\text { State-industry fixed } \\
\text { effects }\end{array}$ & YES & YES & YES & YES \\
\hline Industry time trends & YES & YES & YES & YES \\
\hline Year effects & YES & YES & YES & YES \\
\hline $\mathrm{R}^{2}$ & 0.94 & 0.96 & 0.94 & 0.64 \\
\hline Observations & 22883 & 22883 & 22883 & 22883 \\
\hline
\end{tabular}

Source: Aghion, Burgess, Redding and Zilibotti (2003). Standard errors adjusted for clustering by state-industry. Absolute t statistics in parenthesis. *significant $10 \%$ level, ** significant $5 \%$ level, ***significant $1 \%$ level. Pre-reform technological capability is pre-reform stateindustry labour productivity relative to the state with the highest level of pre-reform labour productivity within the industry. Reform is a dummy which equals 0 before 1990 and equals 1 from 1990 onwards. State amendments to the Industrial Disputes Act are coded 1=proworker, $0=$ neutral, $-1=$ pro-employer and then cumulated over the period to generate the labor regulation measure. Sample is a three dimensional unbalanced panel of 3-digit industries in the 16 main Indian states 1980-1997. 


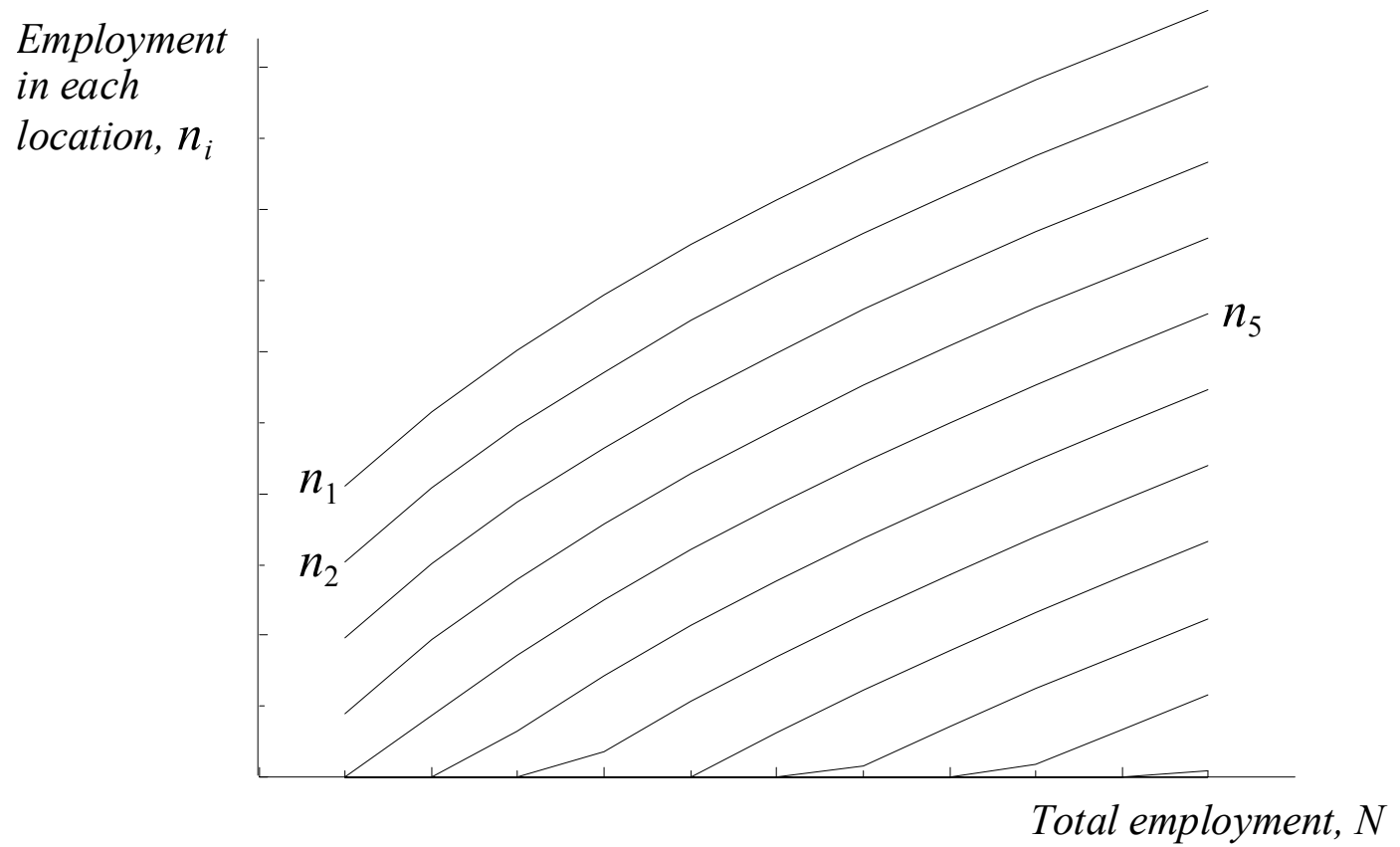

Figure 1: Development without 2nd advantage

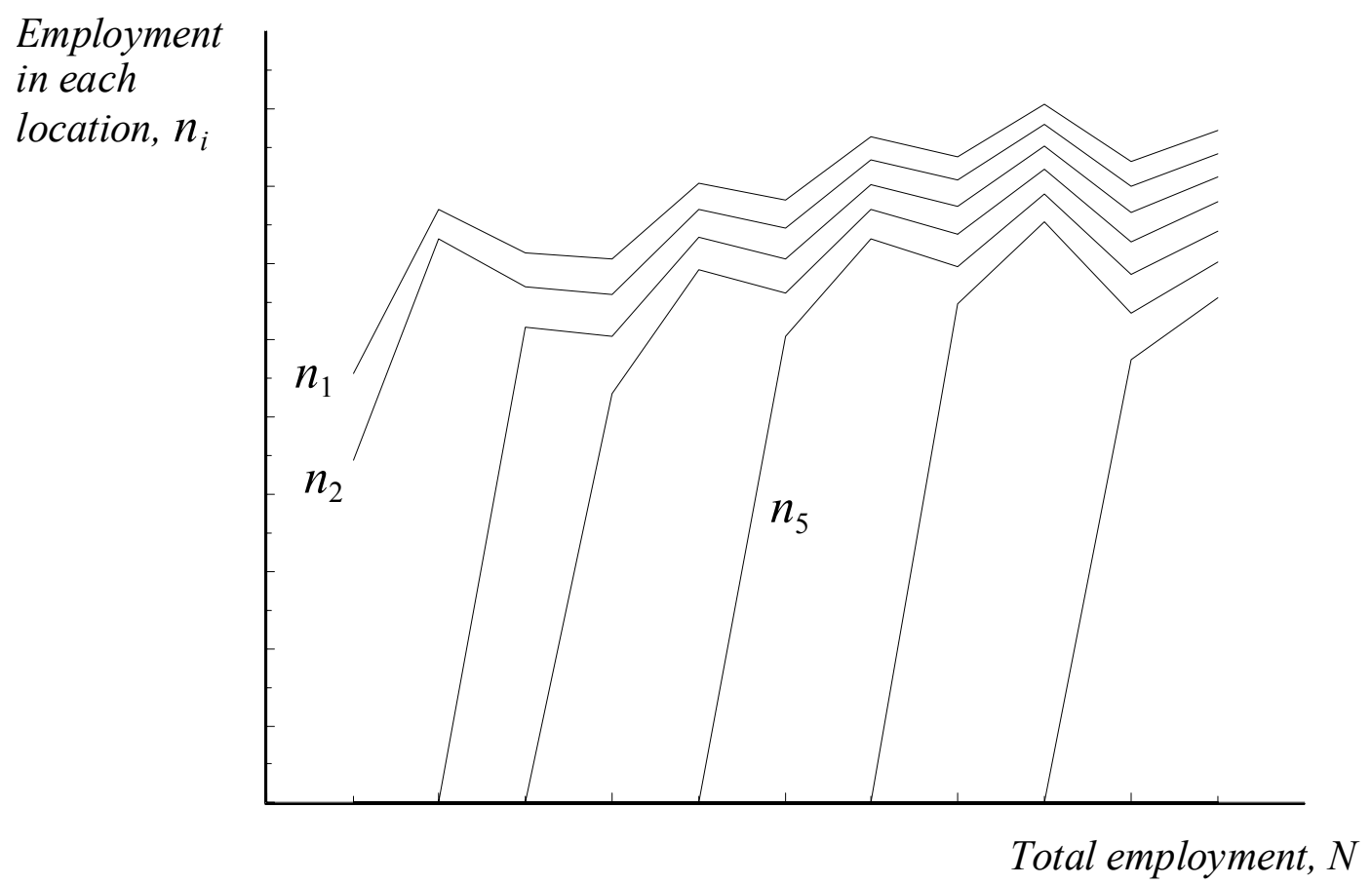

Figure 2: Development with 1st and 2nd advantage 
- agricultural output per capita

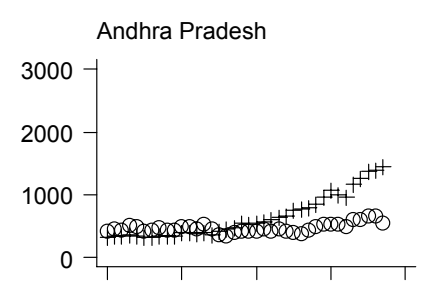

Haryana

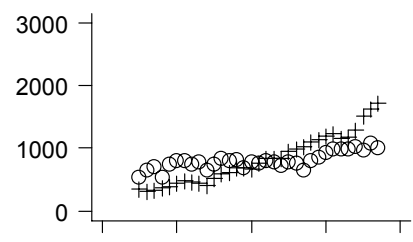

Madhya Pradesh

3000

2000

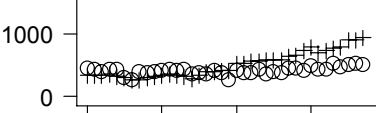

Rajasthan

3000

2000

1000

190

$\begin{array}{llll}1960 & 1970 & 1980 & 19902000\end{array}$
Assam

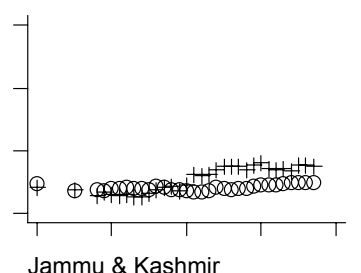

Jammu \& Kashmir

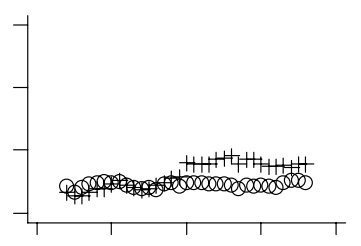

Maharashtra

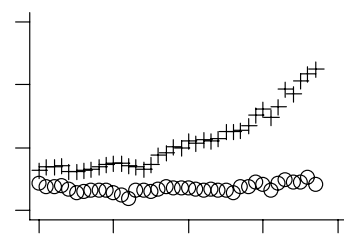

Tamil Nadu

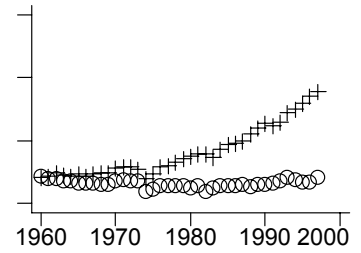

non-agricultural output per cap

Bihar



Karnataka

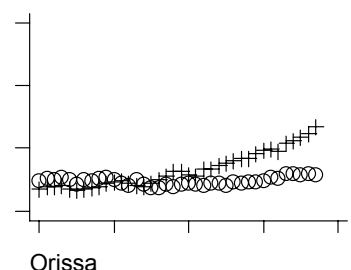

Orissa

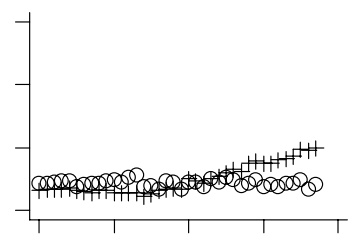

Uttar Pradesh

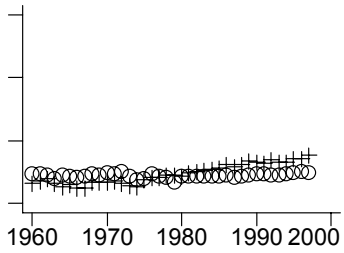

Gujarat

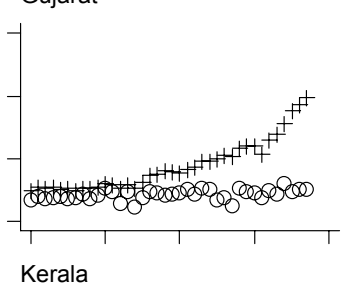

Kerala

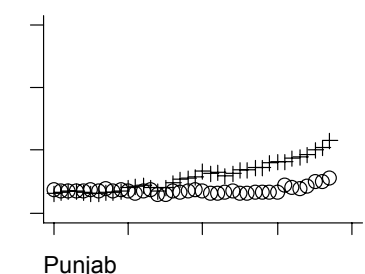

Punjab

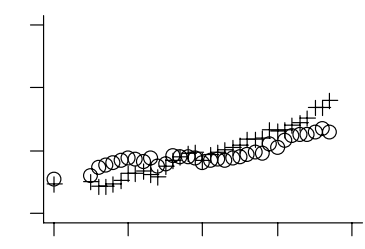

West Bengal

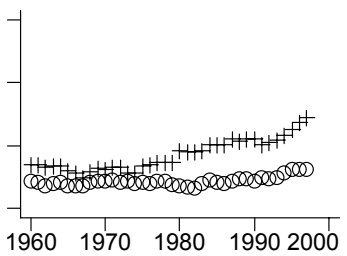

Figure 3: Output Per Capita In India 
- $\quad$ registered manufacturing output
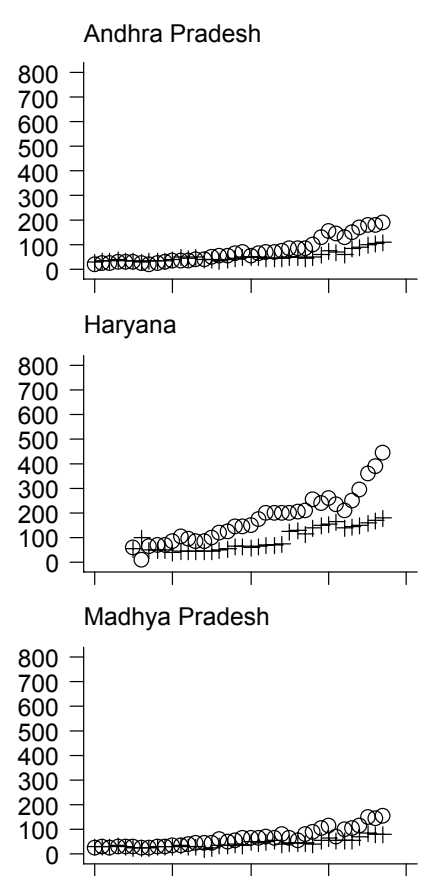

Rajasthan

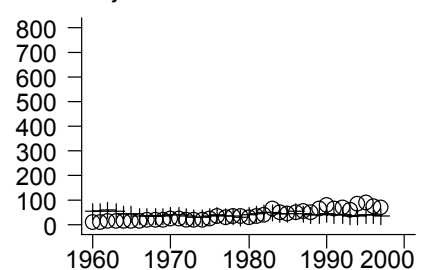

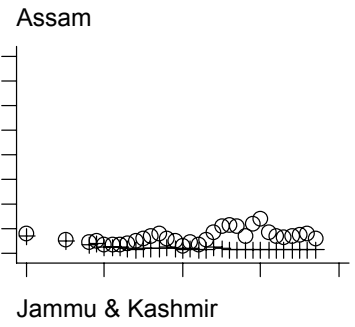

Jammu \& Kashmir



Maharashtra



Tamil Nadu

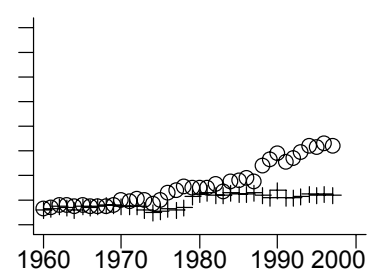

$+\quad$ unregistered manufacturing outp

Bihar

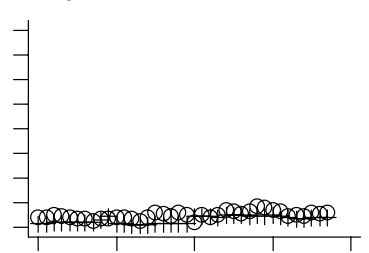

Karnataka


Uttar Pradesh



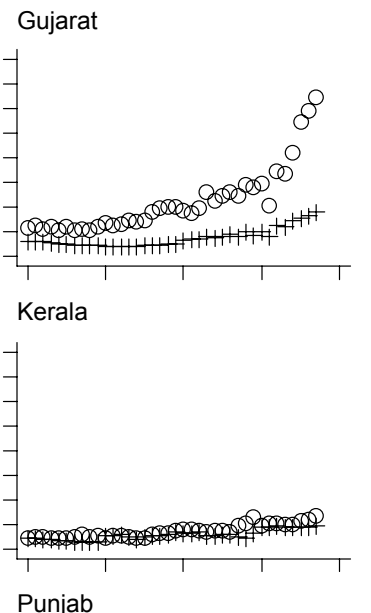

Punjab

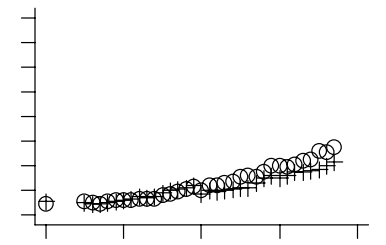

West Bengal



Figure 4: Manufacturing Output Per Capita in India 
- rural poverty headcount

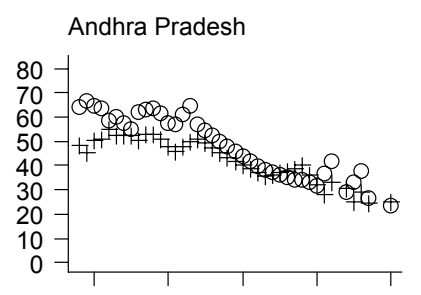

Haryana

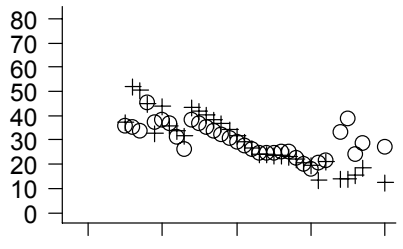

Madhya Pradesh



Rajasthan

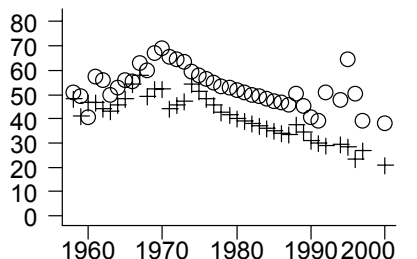

Assam

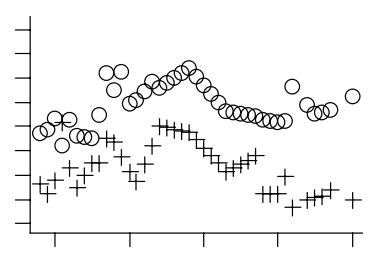

Jammu \& Kashmir

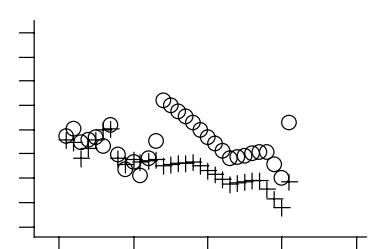

Maharashtra

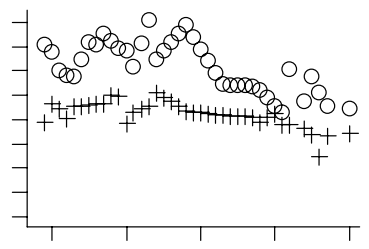

Tamil Nadu

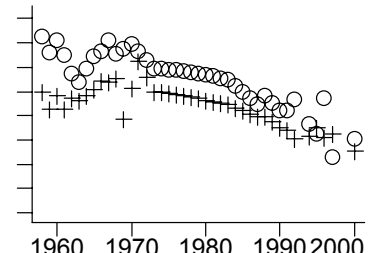

urban poverty headcount

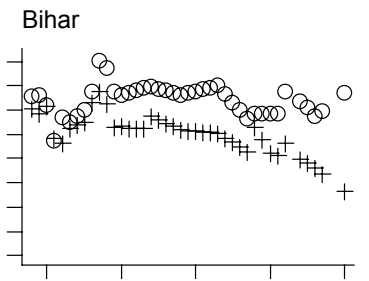

Karnataka

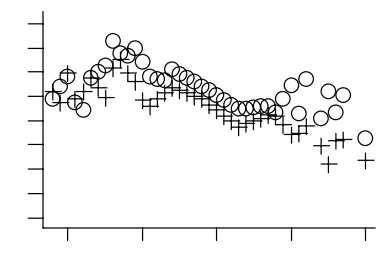

Orissa

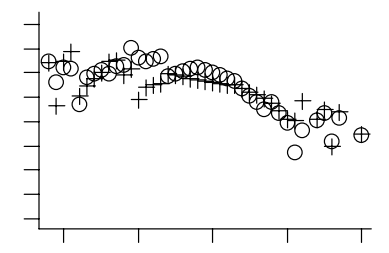

Uttar Pradesh

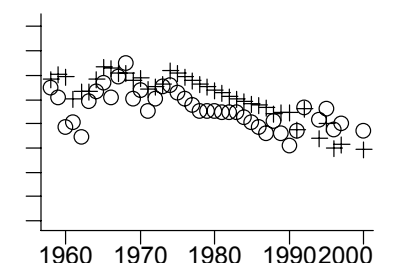

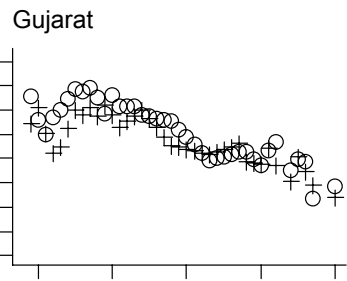

Kerala

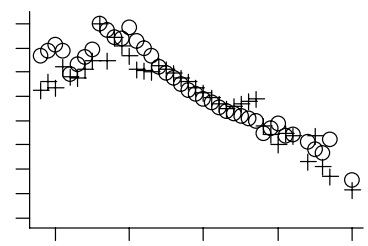

Punjab

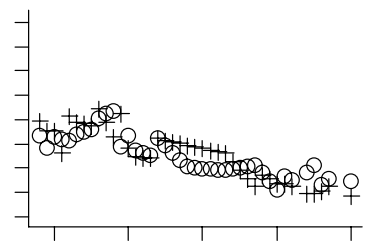

West Bengal

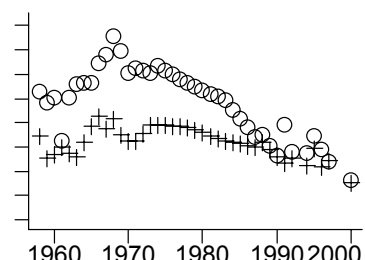

\section{Figure 5: Rural and Urban Poverty in India}





Karnataka

Kerala
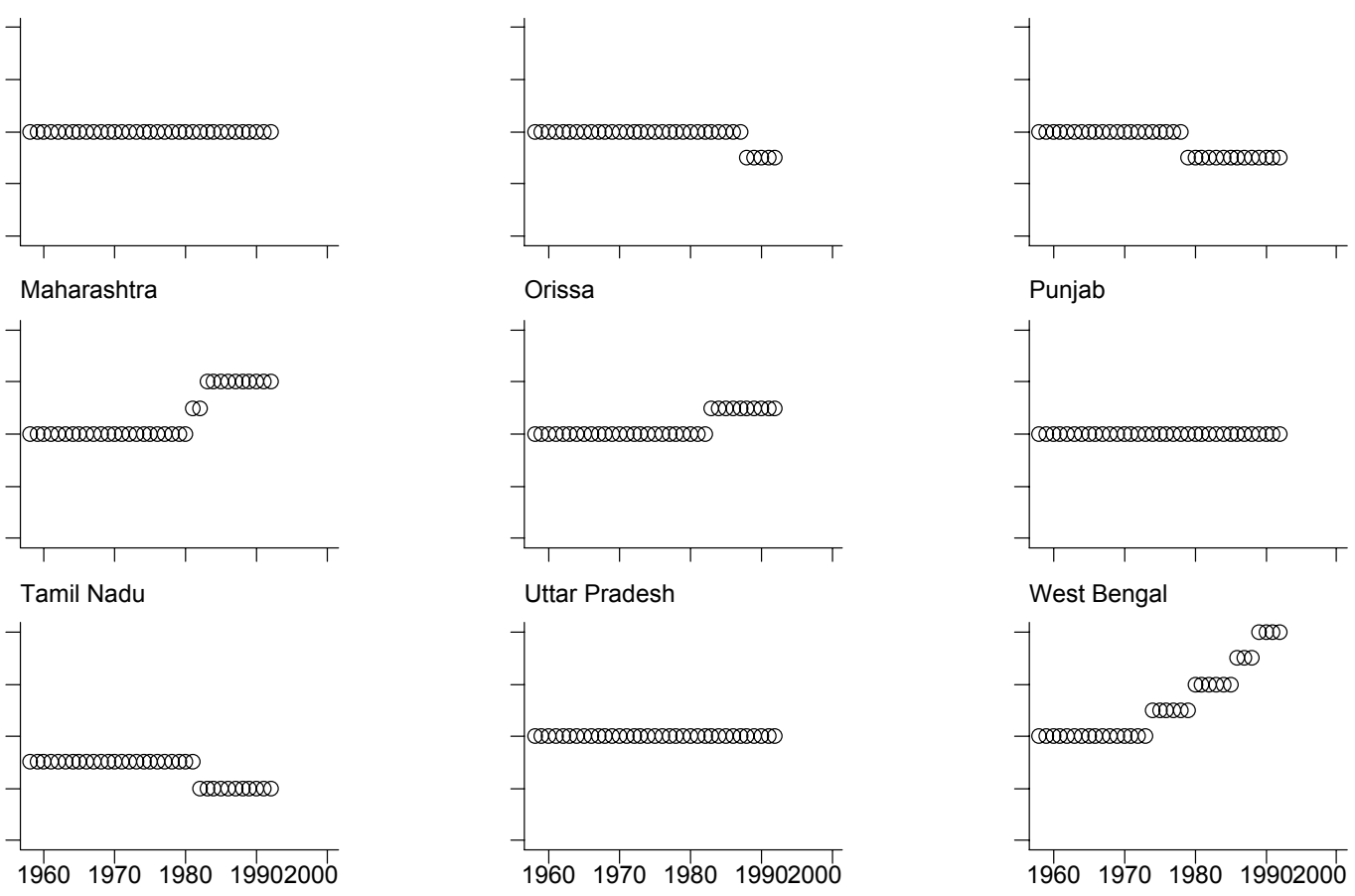

Figure 6: Labour Regulation in India 
Table 1: Poverty and Output in India

\begin{tabular}{|c|c|c|c|c|c|}
\hline & (1) & (2) & (3) & (4) & (5) \\
\hline & $\begin{array}{c}\text { Total } \\
\text { poverty } \\
\text { headcount }\end{array}$ & $\begin{array}{c}\text { Urban } \\
\text { poverty } \\
\text { headcount }\end{array}$ & $\begin{array}{c}\text { Rural } \\
\text { poverty } \\
\text { headcount }\end{array}$ & $\begin{array}{c}\text { Urban } \\
\text { poverty } \\
\text { headcount }\end{array}$ & $\begin{array}{c}\text { Rural } \\
\text { poverty } \\
\text { headcount }\end{array}$ \\
\hline Model & OLS & OLS & OLS & OLS & OLS \\
\hline $\begin{array}{c}\text { Log ag output } \\
\text { pc }\end{array}$ & $\begin{array}{c}4.22 \\
(1.37)\end{array}$ & $\begin{array}{c}1.46 \\
(0.48)\end{array}$ & $\begin{array}{c}4.60 \\
(1.27)\end{array}$ & $\begin{array}{c}1.53 \\
(0.56)\end{array}$ & $\begin{array}{c}3.49 \\
(0.91)\end{array}$ \\
\hline $\begin{array}{l}\text { Log non-ag } \\
\text { output pc }\end{array}$ & $\begin{array}{c}-16.27 * * * \\
(3.00)\end{array}$ & $\begin{array}{c}-9.34 * * * \\
(2.42)\end{array}$ & $\begin{array}{c}-16.18^{* * * *} \\
(2.23)\end{array}$ & & \\
\hline $\begin{array}{l}\text { Log reg manu } \\
\text { output pc }\end{array}$ & & & & $\begin{array}{c}-4.51 * * * \\
(3.20)\end{array}$ & $\begin{array}{l}-0.40 \\
(0.15)\end{array}$ \\
\hline Log unreg & & & & -1.91 & $-5.99 * * *$ \\
\hline $\begin{array}{l}\text { manu output } \\
\text { pc }\end{array}$ & & & & $(1.65)$ & $(2.52)$ \\
\hline State effects & YES & YES & YES & YES & YES \\
\hline Year effects & YES & YES & YES & YES & YES \\
\hline Adjusted $\mathrm{R}^{2}$ & 0.83 & 0.88 & 0.79 & 0.89 & 0.79 \\
\hline Observations & 318 & 318 & 318 & 318 & 318 \\
\hline
\end{tabular}

Table 2: Labour Regulation and Manufacturing Output in India

\begin{tabular}{cccccc}
\hline \hline & $(1)$ & $(2)$ & $(3)$ & $(4)$ & $(5)$ \\
\hline & $\begin{array}{c}\text { Log total } \\
\text { manu output } \\
\text { pc }\end{array}$ & $\begin{array}{c}\text { Log reg } \\
\text { manu output } \\
\text { pc }\end{array}$ & $\begin{array}{c}\text { Log unreg } \\
\text { manu output } \\
\text { pc }\end{array}$ & $\begin{array}{c}\text { Urban } \\
\text { poverty } \\
\text { headcount }\end{array}$ & $\begin{array}{c}\text { Rural } \\
\text { poverty } \\
\text { headcount }\end{array}$ \\
\hline Model & OLS & OLS & OLS & OLS & OLS \\
\hline Labour & $-0.073^{* *}$ & $-0.186^{* * *}$ & $0.086^{* *}$ & $2.288^{* * *}$ & -0.821 \\
regulation [t-1] & $(2.05)$ & $(2.90)$ & $(2.46)$ & $(3.31)$ & $(0.48)$ \\
State effects & YES & YES & YES & YES & YES \\
Year effects & YES & YES & YES & YES & YES \\
Adjusted R & 0.93 & 0.93 & 0.75 & 0.89 & 0.80 \\
Observations & 509 & 508 & 509 & 547 & 547 \\
\hline \hline
\end{tabular}

Source Besley and Burgess (2002). Standard errors adjusted for clustering by state. Absolute t statistics in parenthesis.* significant $10 \%$ level, ** significant $5 \%$ level, *** significant $1 \%$ level. Registered and unregistered manufacturing output are in log real per capita terms. Poverty headcount is the percentage of the population below the official Indian poverty lines which are separately defined for rural and urban areas. State amendments to the Industrial Disputes Act are coded 1=pro-worker, $0=$ neutral, $-1=$ pro-employer and then cumulated over the period to generate the labor regulation measure. The data are for the sixteen main states for the period $1958-1992$. 
Table 3: Rural Banks and Manufacturing Output in India

\begin{tabular}{|c|c|c|c|c|c|}
\hline & (1) & (2) & (3) & (4) & (5) \\
\hline & $\begin{array}{c}\text { Log total } \\
\text { manu output } \\
\text { pc }\end{array}$ & $\begin{array}{c}\text { Log reg } \\
\text { manu output } \\
\text { pc }\end{array}$ & $\begin{array}{l}\text { Log unreg } \\
\text { manu output } \\
\text { pc }\end{array}$ & $\begin{array}{c}\text { Rural } \\
\text { poverty } \\
\text { headcount }\end{array}$ & $\begin{array}{c}\text { Urban } \\
\text { poverty } \\
\text { headcount }\end{array}$ \\
\hline Model & IV & IV & IV & IV & IV \\
\hline No. branches & $-0.15 *$ & 0.04 & $0.28 *$ & $-5.02 * *$ & -0.82 \\
\hline $\begin{array}{c}\text { opened in rural } \\
\text { unbanked } \\
\text { locations pc }\end{array}$ & $(2.10)$ & $(0.57)$ & $(1.85)$ & $(2.14)$ & $(0.92)$ \\
\hline State effects & YES & YES & YES & YES & YES \\
\hline Year effects & YES & YES & YES & YES & YES \\
\hline Adjusted $\mathrm{R}^{2}$ & 0.94 & 0.94 & 0.81 & 0.75 & 0.92 \\
\hline Observations & 579 & 579 & 579 & 627 & 627 \\
\hline
\end{tabular}

Source: Burgess and Pande (2003). Standard errors adjusted for clustering by state. Absolute t statistics in parenthesis. *significant $10 \%$ level, ** significant $5 \%$ level, *** significant $1 \%$ level. Registered and unregistered manufacturing output are in log real per capita terms. Poverty headcount is the percentage of the population below the official Indian poverty lines which are separately defined for rural and urban areas. The number of branches in rural unbanked locations is normalized by 1961 population. The two instruments for this variable are the number of banked locations in 1961 per capita interacted with (i) an indicator variable which equals one if the year>1976 and a post 1976 time trend (ii) an indicator variable which equals one if the year $>1989$ and a post 1989 time trend respectively. Sample is a panel of the 16 main Indian states for the period 1961-2000.

Table 4: Technological Capability, Liberalization and Manufacturing Performance in India

\begin{tabular}{|c|c|c|c|c|}
\hline & (1) & (2) & (3) & (4) \\
\hline & $\begin{array}{l}\text { Log total reg } \\
\text { manu output }\end{array}$ & $\begin{array}{c}\text { Log reg manu } \\
\text { employment }\end{array}$ & $\begin{array}{c}\text { Log reg man } \\
\text { output per } \\
\text { worker }\end{array}$ & $\begin{array}{l}\text { Log total factor } \\
\text { productivity }\end{array}$ \\
\hline Model & IV & IV & IV & IV \\
\hline $\begin{array}{l}\text { Pre-reform tech } \\
\text { capability*reform }\end{array}$ & $\begin{array}{l}0.439 * * * \\
(4.66)\end{array}$ & $\begin{array}{l}0.211 * * * \\
(2.85)\end{array}$ & $\begin{array}{c}0.228 * * * \\
(3.37)\end{array}$ & $\begin{array}{c}0.159 * * * \\
(2.44)\end{array}$ \\
\hline Labour regulation & $\begin{array}{c}-0.090 * * * \\
(3.88)\end{array}$ & $\begin{array}{c}-0.035^{*} \\
(1.69)\end{array}$ & $\begin{array}{c}-0.055^{* *} \\
(1.98)\end{array}$ & $\begin{array}{c}-0.070 * * * \\
(3.13)\end{array}$ \\
\hline $\begin{array}{l}\text { Labour regulation } \\
*_{\text {reform }}\end{array}$ & $\begin{array}{c}-0.061 * * * \\
(4.38)\end{array}$ & $\begin{array}{c}-0.052 * * * \\
(4.39)\end{array}$ & $\begin{array}{l}-0.010 \\
(0.17)\end{array}$ & $\begin{array}{c}-0.036 * * * \\
(4.12)\end{array}$ \\
\hline $\begin{array}{l}\text { State-industry fixed } \\
\text { effects }\end{array}$ & YES & YES & YES & YES \\
\hline Industry time trends & YES & YES & YES & YES \\
\hline Year effects & YES & YES & YES & YES \\
\hline $\mathrm{R}^{2}$ & 0.94 & 0.96 & 0.94 & 0.64 \\
\hline Observations & 22883 & 22883 & 22883 & 22883 \\
\hline
\end{tabular}

Source: Aghion, Burgess, Redding and Zilibotti (2003). Standard errors adjusted for clustering by state-industry. Absolute t statistics in parenthesis. *significant $10 \%$ level, ${ }^{* *}$ significant $5 \%$ level, $* * *$ significant $1 \%$ level. Pre-reform technological capability is pre-reform stateindustry labour productivity relative to the state with the highest level of pre-reform labour productivity within the industry. Reform is a dummy which equals 0 before 1990 and equals 1 from 1990 onwards. State amendments to the Industrial Disputes Act are coded 1=proworker, $0=$ neutral, $-1=$ pro-employer and then cumulated over the period to generate the labor regulation measure. Sample is a three dimensional unbalanced panel of 3-digit industries in the 16 main Indian states 1980-1997. 
